\title{
Transgraniczne sprawy rodzinne w relacjach polsko-brytyjskich w obliczu brexitu ${ }^{1}$
}

\begin{abstract}
The purpose of the article is above all to show possible changes in the field of cross-border family matters as a result of Brexit. From a Polish perspective, this topic is particularly socially significant due to the numerous labor migration of Poles to the UK. It is estimated that around one million Poles live in the UK. First, the article presents current sources of law regarding cross-border family matters (EU law, international agreements, internal law). Next, possible solutions to family matters and their strengths and weaknesses were discussed after Brexit. Finally, solutions currently adopted in the UK and the biggest concerns related to them are shown.
\end{abstract}

Keywords: Cross-border family matters, Brexit, conflict of law

\section{Wstęp}

Oficjalnie 31 stycznia 2020 r. Wielka Brytania² opuściła Unię Europejska. Nie jest to jednak koniec procesu opuszczania UE, a nawet moż-

a) Dr, Kolegium Ekonomii, Finansów i Prawa, Instytut Prawa, Uniwersytet Ekonomiczny w Krakowie.

1 Tekst powstał w wyniku realizacji tematu badawczego Transgraniczne sprawy rodzinne pomiędzy Polskq a Wielka Brytaniq. Brexit i co dalej?, finansowanego ze środków Narodowego Centrum Nauki, nr rej. 2018/02/X/HS5/01463, ID 414992.

${ }^{2}$ W tekście używam zamiennie nazw Wielka Brytania i UK. Oficjalna nazwa państwa w języku polskim to Zjednoczone Królestwo Wielkiej Brytanii i Irlandii Północnej, natomiast Wielka Brytania to tzw. polska nazwa krótka państwa, której odpowiedni- 
na powiedzieć, że to dopiero początek drogi, ponieważ nie doszło jeszcze do wypracowania szczegółów wzajemnych relacji na linii UE - UK. Umowa o wystapieniu UK z dnia 24 stycznia 2020 r. ${ }^{3}$, sfinalizowana ostatecznie przez rząd Borisa Johnsona, zagwarantowała status quo dalsze obwiazzywanie prawa unijnego - do końca okresu przejściowego, tj. do 31 grudnia $2020 \mathrm{r}$.

Dzisiaj brak jest gotowych rozwiązań także w zakresie rodzinnych spraw transgranicznych. UK stoi dopiero przed koniecznościa ich wypracowania. Sytuacją najbardziej pożądana byłoby ich przyjęcie najpóźniej do czasu upływu okresu przejściowego. Wydaje się to coraz mniej realne, z uwagi na trwająca obecnie pandemię Covid-19.

Z perspektywy Polski temat jest społecznie doniosły, od 2010 r. bowiem UK zajmuje pierwsze ${ }^{4}$ miejsce wśród krajów docelowych największej migracji zarobkowej Polaków w XXI w. Według szacunków GUS za 2017 r., w Wielkiej Brytanii mieszka ok. 793 tys. Polaków. Z kolei oficjalne źródła brytyjskie podają wyższe liczby, np. w I kwartale 2016 r.

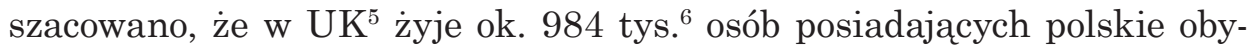
watelstwo, z czego ok. 908 tys. urodziło się na terenie Polski. Dla porównania w 2004 r. w UK mieszkało ok. 69 tys. Polaków ${ }^{7}$ Patrząc na polska

kiem w języku angielskim jest United Kingdom [dalej: UK]; por. Komisja Standaryzacji Nazw Geograficznych poza Granicami Rzeczypospolitej Polskiej przy Głównym Geodecie Kraju: Nazwy państw. Główny Urzqd Geodezji i Kartografii. Warszawa 2006, s. 10, http:// ksng.gugik.gov.pl/pliki/nazwy_panstw.pdf [Dostęp: 9.10.2019 r.]. W języku angielskim nazwa Great Britain odnosi się wyłącznie do Anglii, Szkocji i Walii (bez Irlandii Północnej).

${ }^{3}$ Umowa o wystapieniu Zjednoczonego Królestwa Wielkiej Brytanii i Irlandii Północnej z Unii Europejskiej i Europejskiej Wspólnoty Energii Atomowej. Dz.Urz. UE L nr 29, s. 7 .

${ }^{4}$ Główny Urząd Statystyczny: Informacja o rozmiarach i kierunkach czasowej emigracji z Polski $w$ latach 2004-2016. Warszawa 2017, https://stat.gov.pl/obszary-tema tyczne/ludnosc/migracje-zagraniczne-ludnosci/informacja-o-rozmiarach-i-kierunkachczasowej-emigracji-z-polski-w-latach-2004-2017,2,11.html [Dostęp: 2.04.2019 r.]. Po Wielkiej Brytanii najwięcej polskich emigrantów przebywa, biorąc pod uwagę liczbę ludności, w Niemczech (703 tys.), Holandii (120 tys.) oraz Irlandii (112 tys.).

${ }^{5}$ UK, skrót od United Kingdom, to skrócona oficjalna nazwa państwa - United Kingdom of Great Britain and Northern Ireland, choć międzynarodowy kod państwa, według Międzynarodowej Organizacji Normalizacyjnej, to GB/GBR; por. Guidance Toponymic guidelines for map and other editors, United Kingdom of Great Britain and Northern Ireland. Updated, 17 July 2019, https://www.gov.uk/government/publications/ toponymic-guidelines/toponymic-guidelines-for-map-and-other-editors-united-kingdomof-great-britain-and-northern-ireland\#abbreviations-encountered-in-official-mapping [Dostęp: 9.10.2019 r.].

${ }^{6}$ O. Hawkins, A. Moses: Polish population of the United Kingdom. „Briefing Paper”, CBP7660, 15 July 2016, https://researchbriefings.parliament.uk/ResearchBriefing/ Summary/CBP-7660 [Dostęp: 1.07.2019 r.].

${ }^{7}$ Ibidem. 
emigrację przez pryzmat rodziny, w I kwartale 2016 r. w UK mieszkało ok. 433 tys. polskich rodzin (na 29,9 mln wszystkich rodzin), z czego małżeństwa z dziećmi stanowiły ok. 114 tys. osób ${ }^{8}$.

Rozłączenie rodzin wynikające $\mathrm{z}$ imigracji pociaga za sobą wzrost spraw między małżonkami (zwłaszcza majątkowych) — o rozwód, alimenty na rzecz dzieci i byłego małżonka, sprawowanie opieki nad dziećmi itp. Tego typu sprawy na pograniczu dwóch różnych państw to domena prawa prywatnego międzynarodowego, które określa reguły jurysdykcji międzynarodowej, prawa właściwego oraz skuteczności zagranicznych orzeczeń. W sprawach rodzinnych bardzo ważną rolę odgrywa także administracyjna współpraca między państwami, oparta na sieci specjalnie wyznaczonych w tym celu organów centralnych (np. w zakresie uprowadzeń rodzicielskich, alimentów, adopcji zagranicznej).

Specyfika pierwszych lat po emigracji jest rozdzielenie rodziny między dwa państwa. Ponadto w omawianych sytuacjach aktualizować się będzie problematyka wzajemnego uznawania i wykonywania orzeczeń, ponieważ nawet $\mathrm{w}$ sytuacji, w której rodzina nuklearna w całości zamieszkuje $\mathrm{w}$ danym państwie, mogą nadal trwać relacje majątkowe (np. własność nieruchomości, niespłacone długi, nienaprawiona szkoda) w drugim państwie.

$\mathrm{Na}$ wstępie warto także zasygnalizować, że obywatelstwo jako więź prawna danej osoby z konkretnym państwem ma w dalszym ciagu znaczenie, szczególnie w sprawach rodzinnych. Oznacza to, że osoba mieszkająca w państwie „nieojczystym” wciąż musi się liczyć z możliwościa zastosowania prawa ojczystego (np. Polak mieszkający w UK). Ogólnie jednak także w sprawach rodzinnych obywatelstwo jest wypierane przez łącznik zwykłego pobytu. W zakresie prawa właściwego oznacza to jednolite traktowanie na danym terytorium wszystkich mieszkańców (niezależnie od obywatelstwa).

\section{2. Źródła prawa w zakresie transgranicznych spraw rodzinnych w Polsce i UK}

Początkowo w każdym państwie obowiązywały krajowe zasady międzynarodowego prawa prywatnego i postępowania cywilnego. Gdy prawo unijne zaczęło obowiązywać w Polsce (w szerszym zakresie) oraz w UK

8 Ibidem. 
(w węższym zakresie), 1) w obu państwach przestały być stosowane reguły krajowe; 2) w obu państwach zaczęły częściowo obowiązywać te same reguły. W uwagi na brexit w przyszłości sytuacja się jeszcze bardziej skomplikuje, ponieważ UK wróci do stosowania prawa krajowego, chyba że umowami międzynarodowymi z UE (bilateralnie) i z udziałem UE (multilateralnie) prawo zostanie ponownie ujednolicone. Rzecz jasna, nie można rozstrzygnąć, co będzie w konkretnym wypadku korzystniejsze dla danej rodziny emigrantów: zastosowanie prawa krajowego czy ujednoliconego. Natomiast dla systemu prawa ujmowanego generalnie ujednolicenie oznacza uproszczenie i jest pożądane.

\subsection{Prawo unijne w UK}

United Kingdom jako członek UE było związane prawem unijnym na podstawie European Community Act z 1972 r. ${ }^{9}$, ustawy zaliczanej do ustawodawstwa głównego, nowelizowanej często w drodze ustaw pochodnych przyjmowanych na podstawie Act to Deal with the Mechanics to Implementation $^{10}$. Umowa międzynarodowa $\mathrm{w}$ prawie UK nie wywołuje skutków ipso iure, lecz wymaga implementacji.

Wielka Brytania, podobnie jak Dania, nigdy nie uczestniczyła w pełnym zakresie $\mathrm{w}$ unijnej polityce przestrzeni wolności, bezpieczeństwa i sprawiedliwości (PWBS). Podczas negocjacji traktatu amsterdamskiego w 1996 r. Zjednoczone Królestwo uzyskało prawo do niewiązania się (opt out) różnymi inicjatywami prawnymi podejmowanymi przez UE w dziedzinie współpracy policyjnej i sądowej ${ }^{11}$. Aktualnie na podstawie protokołu nr 21 i $22^{12}$ do TFUE Zjednoczone Królestwo i Irlandia nie sa

${ }^{9} \mathrm{Na}$ jej podstawie ratyfikowano w UK Treaty concerning the accession of the Kingdom of Denmark, Ireland, the Kingdom of Norway and the United Kingdom of Great Britain and Northern Ireland to the European Economic Community and to the European Atomic Energy Community z 22.01.1972 r.; jest to odpowiednik polskiej ścieżki ratyfikacji za uprzednią zgodą wyrażoną w formie ustawy.

${ }_{10}$ A. Dickinson: United Kingdom. In: Encyclopedia of private international law, National reports. Vol. 3. Eds. J. Basedow, G. Rühl, F. Ferrari, P. de M. Asensio. Cheltenham, Edward Elgar Publishing, 2017, s. 2612.

${ }^{11}$ D. Curtin: The ties that bind. Securing information-sharing after Brexit. In: Brexit and Beyond: Rethinking the Futures of Europe. Eds. B. Martill, U. Staiger. UCL Press 2018, doi: 10.2307/j.ctt20krxf8, https://www.jstor.org/stable/j.ctt20krxf8, s. 148.

${ }_{12}$ Protokół w sprawie stanowiska Zjednoczonego Królestwa i Irlandii w odniesieniu do przestrzeni wolności, bezpieczeństwa i sprawiedliwości, Protokół dodany traktatem z dnia 2 października 1997 r. (Dz.U. 2004, nr 90, poz. 864[31]), który wchodzi w życie 1 maja 2004 r.; tytuł zmieniony traktatem z dnia 13 grudnia 2007 r. (Dz.U. 2009, nr 203, poz. 1569), który wchodzi w życie 1 grudnia 2009 r. 
związane. Nie mają też do nich zastosowania środki przyjęte $\mathrm{w}$ ramach przestrzeni wolności, sprawiedliwości i bezpieczeństwa, chyba że same zdecyduja się do nich przystapić ${ }^{13}$. Z jednej strony jest to przeszkoda w unifikacji prawa prywatnego międzynarodowego w całej UE, z drugiej strony zaś istniejący model współpracy UK - UE w zakresie współpracy sądowej w sprawach cywilnych może być wykorzystany i rozwijany po brexicie $^{14}$.

United Kingdom w zakresie spraw rodzinnych ${ }^{15}$ związało się m.in. rozporządzeniem nr 2201/2003 z dnia 27 listopada 2003 r. dotyczacym jurysdykcji oraz uznawania i wykonywania orzeczeń w sprawach małżeńskich oraz $\mathrm{w}$ sprawach dotyczących odpowiedzialności rodzicielskiej, uchylającym rozporządzenie (WE) nr 1347/2000 ${ }^{16}$ [dalej: Bruksela II bis], oraz rozporządzeniem nr 4/2009 z dnia 18 grudnia 2008 r. w sprawie jurysdykcji, prawa właściwego, uznawania i wykonywania orzeczeń oraz współpracy $\mathrm{w}$ zakresie zobowiązań alimentacyjnych ${ }^{17}$ [dalej: rozporządzenie $\mathrm{nr} 4 / 2009$ ], po jego przyjęciu ${ }^{18}$, wyłącznie w zakresie, w jakim nie dotyczy prawa właściwego ${ }^{19}$, a więc bez art. 15 tego rozporządzenia.

${ }_{13}$ Moga to zrobić w terminie 3 miesięcy od przedstawienia Radzie propozycji lub inicjatywy, lub w każdym czasie po przyjęciu środka przez Radę.

${ }^{14}$ M. Pilich: Brexit and EU private international law: May the UK stay in?. „Maastricht Journal of European and Comparative Law” August 2017, 20 (10), doi: 10.1177/1023263X17722327, s. 15-16.

${ }_{15}$ Dla spraw rodzinnych znaczenie mają rozporządzenia: rozporządzenie nr 393/2007 z dnia 13 listopada 2007 r. dotyczące doręczania w państwach członkowskich dokumentów sądowych i pozasądowych w sprawach cywilnych i handlowych; rozporządzenie nr 1206/2001 z dnia 28 maja 2001 r. w sprawie współpracy między sądami państw członkowskich przy przeprowadzaniu dowodów w sprawach cywilnych lub handlowych; rozporządzenie nr 805/2004 z dnia 21 kwietnia 2004 r. w sprawie utworzenia Europejskiego Tytułu Egzekucyjnego dla roszczeń bezspornych; rozporządzenie nr 2016/1191 z dnia 6 lipca 2016 r. w sprawie promowania swobodnego przepływu obywateli przez uproszczenie wymogów dotyczących przedkładania określonych dokumentów urzędowych w Unii Europejskiej i zmieniające rozporządzenie (UE) nr 1024/2012 oraz decyzja Rady 2001/470/WE z dnia 28 maja 2001 r. ustanawiająca Europejską Sieć Sądową w sprawach cywilnych i handlowych.

${ }_{16}$ Dz.Urz. UE L nr 338 z dnia 23.12.2003, s. 1.

${ }_{17}$ Dz.Urz. UE L nr 7 z dnia 10.01.2009, s. 1.

${ }^{18} \mathrm{Na}$ podstawie decyzji Komisji z dnia 8 czerwca 2009 r., dotyczącej zamiaru przyjęcia przez Zjednoczone Królestwo rozporządzenia Rady (WE) nr 4/2009 w sprawie jurysdykcji, prawa właściwego, uznawania i wykonywania orzeczeń oraz współpracy w zakresie zobowiązań alimentacyjnych (2009/451/WE; Dz.Urz. UE 2009 L nr 149/73).

${ }_{19}$ UK nie związało się protokołem haskim o prawie właściwym dla zobowiązań alimentacyjnych, co ma znaczenie przede wszystkim dla uznawania i wykonalności orzeczeń, dokumentów urzędowych i ugód sądowych (art. 16 ust. 3 oraz art. 23-38 rozporządzenia nr 4/2009). 
Zasadniczo UK przystąpiło do większości unijnych rozporządzeń w zakresie jurysdykcji, skuteczności zagranicznych orzeczeń oraz szeroko pojętego dostępu do wymiaru sprawiedliwości, natomiast nie związało się unijnymi normami kolizyjnymi wskazującymi prawo właściwe dla szeroko pojętych spraw rodzinnych, w tym dla alimentów ${ }^{20}$, dla rozwodu i separacji ${ }^{21}$, dotyczących małżeńskich/partnerskich skutków majątkowych $^{22}$. Jest to po części wynikiem traktowania prawa obcego jako faktu, który podlega dowodzeniu przed sądem. Prawo obce może być przez sąd brytyjski uwzględnione tylko na wniosek strony, w przeciwieństwie do prawa brytyjskiego, prawo obce nie jest stosowane $\mathrm{z}$ urzędu ${ }^{23}$.

Prawo unijne tworzy autonomiczny porządek prawny i korzysta z pierwszeństwa stosowania przed prawem krajowym. Gwarantuje ono w sprawach małżeńskich (rozwód, separacja, unieważnienie małżeństwa), odpowiedzialności rodzicielskiej (łącznie z bezprawnym uprowadzeniem dziecka):

1. Jednolite reguły jurysdykcji sądów państw członkowskich w sprawach transgranicznych, opartych na miejscu zwykłego pobytu wnioskodawcy (dziecka, osoby uprawnionej do alimentów, małżonka) ${ }^{24}$.

2. Automatyczne uznawanie i wykonywanie orzeczeń. Prawo UE zapewnia, że decyzje dotyczące opieki nad dziećmi, kontaktów z nimi, alimentów wydane $\mathrm{w}$ jednym państwie członkowskim mogą być automatycznie uznawane i wykonywane w każdym innym państwie członkowskim. Z uwagi na niezwiązanie się UK protokołem haskim z 2007 r. o prawie właściwym dla zobowiązań alimentacyjnych ${ }^{25}$ wyłacznie polskie orzeczenia o alimentach sa w UK automatycznie wykonywane, natomiast brytyjskie orzeczenia alimentacyjne wymagaja

${ }^{20}$ Rozporządzenie nr 4/2009.

${ }^{21}$ Rozporządzenie $\mathrm{nr}$ 1259/2010 z dnia 20 grudnia 2010 r. w sprawie wprowadzenia w życie wzmocnionej współpracy w dziedzinie prawa właściwego dla rozwodu i separacji prawnej. Dz.Urz. UE L nr 343, 29.12.2010, s. 10.

${ }^{22}$ Dwa rozporządzenia regulujace kompleksowo jurysdykcję, prawo właściwe oraz skuteczność zagranicznych orzeczeń z dnia 24 czerwca 2016 r.: 1) nr 2016/1103 wdrażajace wzmocnioną współpracę w dziedzinie jurysdykcji, prawa właściwego oraz uznawania i wykonywania orzeczeń w sprawach dotyczących małżeńskich ustrojów majątkowych. Dz.Urz. UE L nr 183, 8.07.2016, s. 1; 2) nr 2016/1104 z dnia 24 czerwca 2016 r. wdrażajace wzmocnioną współpracę w dziedzinie jurysdykcji, prawa właściwego oraz uznawania i wykonywania orzeczeń w sprawach dotyczących skutków majątkowych zarejestrowanych związków partnerskich. Dz.Urz. UE L nr 183, 8.07.2016, s. 30.

${ }^{23}$ A. Dickinson: United Kingdom..., s. 2616.

${ }^{24}$ M. Doyle: The impact of Brexit on children and young people in Scotland, Case study on cross-border family law. Together (Scottish Alliance for Children's Rights), s. 9-10.

25 2009/941/WE: Decyzja Rady z dnia 30 listopada 2009 r. w sprawie zawarcia przez Wspólnotę Europejską Protokołu haskiego z dnia 23 listopada 2007 r. o prawie właściwym dla zobowiązań alimentacyjnych. Dz.Urz. UE L nr 331, 16.12.2009, s. 17-18. 
w Polsce stwierdzenia wykonalności ${ }^{26}$. Automatyzm uznawania w połączeniu z automatyzmem wykonania zapewnia dzieciom pewność i bezpieczeństwo w zakresie kontaktów z rodzicem/rodzicami, opieki i alimentów oraz pozwala uniknać opóźnień i kosztów związanych $\mathrm{z}$ zabezpieczeniem nowych roszczeń w innych krajach. Zapobiega to również uchylaniu się przez rodziców od ich obowiązków w stosunku do dzieci przez przeniesienie się do innego kraju.

3. Uwzględnianie najlepszego interesu dziecka. Wszystkie decyzje podjęte na mocy Brukseli II bis muszą leżeć w najlepszym interesie dziecka, zgodnie z art. 24 Karty praw podstawowych $\mathrm{UE}^{27}$ oraz art. 3 Konwencji o prawach dziecka ${ }^{28}$.

4. Wzmocnienie prawa dzieci do uczestnictwa w transgranicznych postępowaniach rodzinnych. W świetle Brukseli II bis decyzje dotyczące opieki, dostępu i powrotu po uprowadzeniu dziecka nie mogą zostać wykonane, jeżeli istnieją dowody na to, że dziecku nie dano możliwości bycia wysłuchanym ${ }^{29}$.

5. Szybkość rozstrzygnięć: w postępowaniu w sprawie powrotu dziecka, zgodnie z art. 11 ust. 3 Brukseli II bis, decyzja musi zostać podjęta co do zasady w ciągu 6 tygodni. Przyspieszeniu postępowania ma służyć także ograniczenie liczby odwołań ${ }^{30}$.

6. Współpracę między państwami, opartą na sieci ustanowionych w każdym państwie organów centralnych oraz jednostek odpowiedzialnych za doręczanie dokumentów sądowych lub pozasądowych oraz przeprowadzanie dowodów za granica.

\subsection{Umowy międzynarodowe}

Źródłem prawa prywatnego międzynarodowego w relacjach polsko-brytyjskich sa także umowy międzynarodowe, zwłaszcza konwencje haskie opracowane przez Haską Konferencję Prawa Prywatnego Międzynarodowego [dalej: $\mathrm{HCCH}$ ], które w dużej mierze zostały zastąione przez unijne rozporządzenia o treści podobnej do treści konwencji.

Wielka Brytania jest członkiem HCCH od 1955 r., z kolei Polska od 1984 r. ${ }^{31}$ Zarówno Polska, jak i UK samodzielnie związały się m.in.:

${ }^{26}$ Według zasad określonych w rozporządzeniu 4/2009 (art. 23-38).

${ }^{27}$ Dz.Urz. UE C nr 326, 26.10.2012, s. 391-407.

${ }^{28}$ Konwencja o prawach dziecka, przyjęta przez Zgromadzenie Ogólne Narodów Zjednoczonych dnia 20 listopada 1989 r. Dz.U. 1991, nr 120, poz. 526.

${ }^{29}$ M.in. art. 23 lit. b, art. 41 ust. 2, art. 42 ust. 2 Brukseli II bis.

${ }^{30}$ M.in. art. 21 ust. 2, art. 34, art. 42 ust. 1, art. 43 ust. 2 Brukseli II bis.

${ }^{31} \mathrm{https} / / / \mathrm{www} . h c c h . n e t / e n /$ states/hcch-members/details1/?sid=75 [Dostęp: 2.04.2019 r.]. 
Konwencją o uznawaniu rozwodów i separacji z dnia 1 czerwca 1970 r. ${ }^{32}$; Konwencją o uznawaniu i wykonywaniu orzeczeń odnoszących się do obowiązków alimentacyjnych z dnia 2 października $1973 \mathrm{r}^{33}$; Konwencją dotycząca cywilnych aspektów uprowadzenia dziecka za granicę z dnia 25 października 1980 r. ${ }^{34}$; Konwencją o ochronie dzieci i współpracy w dziedzinie przysposobienia międzynarodowego z dnia 29 maja 1993 r. $^{35}$; Konwencją o jurysdykcji, prawie właściwym, uznawaniu, wykonywaniu i współpracy w zakresie odpowiedzialności rodzicielskiej oraz środków ochrony dzieci z dnia 19 października 1996 r. $^{36}$

Polska oraz UK sa także stronami Konwencji haskiej z dnia 23 listopada 2007 r. o międzynarodowym dochodzeniu alimentów na rzecz dzieci i innych członków rodziny ${ }^{37}$ [dalej: konwencja haska o dochodzeniu alimentów z 2007 r.], która formalnie związała się UE ze skutkami dla wszystkich państw członkowskich, korzystając z zewnętrznej wyłącznej kompetencji w tym zakresie.

Zarówno Polska, jak i UK są stronami licznych umów dwustronnych dotyczących międzynarodowej procedury cywilnej oraz skuteczności zagranicznych orzeczeń. W relacjach polsko-brytyjskich nie doszło do zawarcia takiej umowy.

Zasadniczo od momentu członkostwa UK (1.01.1973 r.) oraz Polski (1.05.2004 r.) w UE postanowienia umów międzynarodowych ustapiły pierwszeństwa rozporządzeniom unijnym w zakresie regulowanym przez te rozporządzenia.

Porównując zakresy zastosowania prawa unijnego ze wskazanymi konwencjami, warto nadmienić, że prawo unijne, w przeciwieństwie do konwencji haskich, obejmuje także jurysdykcję w sprawach małżeńskich (rozwód, separacja, unieważnienie małżeństwa) oraz w sprawach o alimenty. Powoduje to brak jednolitych reguł jurysdykcyjnych w kręgu państw będących stronami tych konwencji. Oznacza to konieczność stosowania krajowych przepisów regulujących jurysdykcję. Tymczasem, jak podkreśla TSUE, odrzucenie krajowych norm jurysdykcyjnych ułatwia

${ }^{32}$ W UK weszła w życie dnia 24.08.1975 r., w Polsce 11.06.2001 r. Dz.U. 2001, nr 53, poz. 561 .

${ }^{33}$ W UK weszła w życie 1.03.1980 r., w Polsce 31.01.2000 r. Dz.U. 2000, nr 2, poz. 13.

${ }^{34}$ W UK weszła w życie 1.08.1986 r., w Polsce 9.10.1995 r. Dz.U. 1995, nr 108, poz. 528 .

${ }^{35}$ W UK weszła w życie 1.06.2003 r., w Polsce 31.05.2000 r. Dz.U. 2000, nr 39, poz. 448 .

${ }^{36}$ W UK weszła w życie 1.11.2012 r., w Polsce 1.11.2010 r. Dz.U. 2010, nr 39, poz. 448.

${ }^{37}$ Tekst konwencji jako załącznik do decyzji Rady nr 2011/432/UE z dnia 9 czerwca 2011 r. w sprawie zatwierdzenia w imieniu Unii Europejskiej Konwencji haskiej z dnia 23 listopada 2007 r. o międzynarodowym dochodzeniu alimentów na rzecz dzieci i innych członków rodziny. Dz.Urz. UE L nr 192, 2011, s. 39. 
również proces uznawania orzeczeń we wszystkich państwach członkowskich, który stanowi kamień węgielny europejskiego systemu współpracy sądowej w sprawach cywilnych ${ }^{38}$. Istotniejszy jest jednak fakt, że konwencje nie przewiduja automatycznego uznawania orzeczeń wydanych przez sąd jednej ze stron w sprawie rozwodu i separacji ${ }^{39}$ oraz o alimenty ${ }^{40}$.

Nowością w unijnych rozporządzeniach są także jednolite wielojęzyczne formularze wniosków, wyciąó́w z orzeczenia ${ }^{41}$ oraz świadectw orzeczeń w sprawach małżeńskich i odpowiedzialności rodzicielskiej ${ }^{42}$. Unijne rozporządzenia redukują również liczbę wymaganych dokumentów ${ }^{43}$ oraz usprawniają i przyśpieszają administracyjną współpracę między organami centralnymi, co ma szczególne znaczenie dla alimentów, których dochodzenie za granicą było dotychczas nieskuteczne i długotrwałe.

Obowiązujące konwencje nie gwarantuja zatem w takim stopniu, jak prawo unijne swobodnej cyrkulacji zagranicznych orzeczeń ani tak skutecznej współpracy między państwami.

${ }^{38}$ Opinia z dnia 4 września 2014 r., C-400/13 i C-408/13, Sanders. ECLI:EU:C: 2014:2461.

${ }^{39}$ Por. art. 2 Konwencji haskiej o uznawaniu rozwodów i separacji uzależnia ich uznanie od zachowania tzw. jurysdykcji pochodnej. Oznacza to, że sąd wezwany do uznania musi zweryfikować istnienie jednej z podstaw jurysdykcji pochodnej. Uznanie wymaga w takim przypadku przeprowadzenia specjalnego postępowania. Natomiast automatyzm uznania oznacza brak konieczności przeprowadzania postępowania $\mathrm{w}$ sprawie uznania, choć nie zawsze stoi na przeszkodzie złożenia wniosku o uznanie lub nieuznanie orzeczenia (np. art. 21 ust. 1 i 3 Bruskeli II bis, art. 24 Konwencji o jurysdykcji, prawie właściwym, uznawaniu, wykonywaniu i współpracy w zakresie odpowiedzialności rodzicielskiej oraz środków ochrony dzieci). W niektórych przypadkach automatyzm uznawania rozumiany jest „rygorystycznie”, tj. wyklucza możliwość sprzeciwienia się uznaniu orzeczenia (art. 17 ust. 1 rozporządzania nr 4/2009).

${ }^{40}$ Por. art. 20 Konwencji haskiej z 2007 r. o międzynarodowym dochodzeniu alimentów na rzecz dzieci i innych członków rodziny.

41 Jednolite formularze wniosków o uzyskanie, zmianę, o uznanie lub o uznanie i stwierdzenie wykonalności orzeczenia względnie wykonanie orzeczenia w sprawach alimentów, załączniki I-XI rozporządzenia nr 4/2009.

${ }^{42}$ Świadectwo dotyczące orzeczeń w sprawach małżeńskich, w sprawie odpowiedzialności rodzicielskiej, do kontaktów z dzieckiem, dotyczące powrotu dziecka, załączniki I-IV Brukseli II bis.

${ }_{43}$ Por. art. 37 i 39 Brukseli II bis, brak regulacji w konwencji, co oznacza, że w tym zakresie obowiąują regulacje państwa, do którego organu ma wpłynać wniosek o uznanie, stwierdzenie wykonania lub rejestrację w celu wykonania, przy czym każde państwo w odniesieniu do stwierdzenia wykonalności lub zarejestrowania ma obowiązek stosować proste i szybkie postępowanie (art. 26 ust. 2). Zob. art. 20, 28 rozporządzenia nr 4/2009. 


\subsection{Prawo wewnętrzne}

Jeśli chodzi o prawo wewnętrzne na terenie UK, to wyróżniamy trzy systemy prawne: Anglii i Walii, Szkocji oraz Irlandii Północnej. Biorąc pod uwagę normy kolizyjne, zasadniczo Anglia i Walia sa traktowane jako jedno państwo, jednak Walia, Szkocja i Irlandia maja swoje własne organy prawodawcze. Między poszczególnymi systemami prawa prywatnego międzynarodowego w UK występują duże różnice, mimo wspólnego parlamentu, wspólnej władzy wykonawczej oraz sądu najwyższego ${ }^{44}$.

Żaden z systemów prawnych UK nie posiada kodyfikacji prawa prywatnego międzynarodowego. Regulacje $\mathrm{w}$ tym zakresie sa rozproszone w zróżnicowanych źródłach, tzn. w prawie krajowym, unijnym oraz w umowach międzynarodowych.

W systemach prawnych UK ustawy dzielą się na ustawy główne oraz drugorzędne ${ }^{45}$, do tego dochodzą jeszcze różne formy delegowanych aktów prawnych. Fundamentalne znaczenie w UK jako źródło prawa ma orzecznictwo, ze względu na rygorystyczną doktrynę precedensu (stare decises $)^{46}$. Jednak znaczenie orzecznictwa dla prawa prywatnego międzynarodowego zmniejszyło się znacznie w ostatnim półwieczu, ze względu na członkostwo UK w UE oraz rosnącą liczbę przepisów krajowych. Czołowy ekspert $\mathrm{w}$ tej dziedzinie prawa prywatnego międzynarodowego A. Briggs prezentuje stanowisko, że prawo prywatne międzynarodowe w UK nie jest częścią common law, które dostosowało się do nowego prawa unijnego, lecz tworzy europejski system prawa prywatnego międzynarodowego, zawierajacy treść pochodząca z common law ${ }^{47}$.

Podstawowa reguła kolizyjna obowiąujacca w systemach prawnych UK to stosowanie lex fori, tj. własnego prawa (np. w sprawie rozwodu) ${ }^{48}$. Jak wspomniano wcześniej, prawo obce w systemie common law nie jest traktowane jak prawo brytyjskie. Sąd nie musi stosować go z urzędu, jest bowiem traktowane jako fakt, który podlega udowodnieniu, tak jak inne fakty w postępowaniu. Prawo obce jest stosowne wyłącznie na wniosek strony, która wykaże konieczność jego zastosowania w danej sprawie $\mathrm{z}$ pominięciem prawa obowiązującego $\mathrm{w}$ siedzibie sądu. Orzecznictwo dostarcza jednak przykłady odejścia od zasady stosowania własnego prawa. I tak forma zawarcia małżeństwa podlega lex loci celebrationis, z ko-

${ }^{44}$ A. Dickinson: United Kingdom..., s. 2612.

${ }^{45}$ Ibidem; systemy źródeł prawa w UK nie należą do prostych i czytelnych.

${ }^{46}$ Ibidem, s. 2614.

${ }^{47}$ A. Briggs: The conflict of law. 3 th. Oxford University Press 2013, Preface, s. v—vi.

${ }^{48}$ Ibidem, s. 7-10; D. McClean: Morris, The Conflict of Laws. Eds. D. McClean, V. Ruiz Abou-Nigm. 8 th. London 2012, s. 7-12. 
lei możność zawarcia małżeństwa reguluje domicyl każdego z przyszłych małżonków ${ }^{49}$.

$\mathrm{W}$ systemie common law dla conflict of law kluczowe jest pojęcie domicylu, przy czym w UK wyróżnia się dwie kategorie domicylu: domicyl z pochodzenia (domicile of origin) oraz domicyl z wyboru (domicile of choice $)^{50}$. W dalszym ciągu odgrywa w UK ważną rolę w sprawach rodzinnych. Każdy musi mieć domicyl, przy czym można mieć wyłącznie jeden domicyl. $\mathrm{Z}$ chwila urodzenia osobie zostaje przypisany domicyl $\mathrm{z}$ pochodzenia, tj. domicyl rodziców z chwili narodzin dziecka. Może on zostać zmieniony jedynie wskutek wyraźnej woli osoby zainteresowanej, która osiągnęła pełnoletniość. Zmiana domicylu z pochodzenia na domicyl z wyboru w innym państwie wymaga dwóch elementów: pobytu osoby $\mathrm{w}$ tym państwie oraz zamiaru pozostania w tym państwie na stałe lub przez czas nieokreślony.

Stałość powiazania osoby z określonym porządkiem prawnym sprawia, że domicyl z pochodzenia jest porównywany do obywatelstwa. $\mathrm{Na}$ przykład domicyl z pochodzenia może zostać utracony na rzecz domicylu z wyboru, ale zawsze może on zostać przywrócony, gdy domicyl z wyboru zostaje utracony bez uzyskania nowego ${ }^{51}$.

W systemach prawnych UK jurysdykcję sądu wyznacza zasadniczo domicyl pozwanego ${ }^{52}$. W Szkocji, w przeciwieństwie do Anglii, Walii i Irlandii Północnej, jurysdykcja przeciwko pozwanemu, przebywajacemu za granica, nie jest uzależniona od zgody sądu na doręczenie mu za granica pozwu ${ }^{53}$. W zakresie jurysdykcji common law opiera się przede wszystkim na koncepcji forum non conveniens, zgodnie z którą sąd krajowy ma prawo zrezygnować z powierzonej mu przez ustawę jurysdykcji, jeśli uważa, że sąd innego państwa jest bardziej odpowiedni do rozstrzygnięcia sporu.

Z kolei uznawanie i wykonywanie zagranicznych orzeczeń $\mathrm{w}$ sprawach pieniężnych na podstawie ogólnych zasad common law wymaga wcześniejszej rejestracji w $\mathrm{UK}^{54}$. Odrębne reguły obowiązują w zakresie

${ }^{49}$ Brook v Brook (1861), 9H.L.C. 193. Sekcja 38 (1) Family Law (Scotland) Act 2006.

${ }^{50}$ Dicey, Morris and Collins on the Conflict of Laws. Ed. L. Collins. 14 th. London, Sweet\&Maxwell, 2006, s. 122-176; J.J. Fawcett, J.M. Carruthers, P.M. North, Cheshire, North and Fawcett: Private international law. 14 th. Oxford [etc.], Oxford University Press, 2008, s. 153-196.

51 „In fact it (domicile of origin) transcends even nationality in stability and permanence, for though it may be placed in abeyance, it can never be destroyed. To the end of his life a man's domicile of origin retains his capacity for revival". G.C. Cheshire: Private International Law. London 1965, s. 171.

52 A. Dickinson: United Kingdom..., s. 2617.

${ }^{53}$ Civil Jurisdiction and Judgements Act 1982 (sekcja 20).

${ }_{54}$ Foreign Judgments (Reciprocal Enformcement) Act 1933 (c 13(23-24Geo 5)). 
uznawania i wykonywania orzeczeń pochodzących z jednego z systemów prawnych $\mathrm{UK}^{55}$.

Natomiast w polskim prawie wewnętrznym źródłem norm kolizyjnych jest ustawa Prawo prywatne międzynarodowe z dnia 4 lutego $2011 \mathrm{r}^{56}$, a źródłem norm dotyczących międzynarodowego postępowania cywilnego - częśś IV k.p.c. ${ }^{57}$, przy czym reguły jurysdykcji, uznawania i wykonywania zagranicznych orzeczeń sa wzorowane na przepisach rozporzadzenia nr 44/2001 w sprawie jurysdykcji i uznawania orzeczeń sądowych oraz ich wykonywania w sprawach cywilnych i handlowych ${ }^{58}$ [dalej: Bruksela I]. W 2008 r. doszło do nowelizacji ${ }^{59}$ k.p.c., na skutek której „udomowiono” przepisy Brukseli I, co oznacza, że do 10 stycznia 2014 r. ${ }^{60}$ w Polsce stosowało się jednakowe reguły w zakresie skuteczności zagranicznych orzeczeń w odniesieniu do wszystkich państw. Także podstawy jurysdykcji sądów polskich w sprawach cywilnych, handlowych, małżeńskich, relacji między rodzicami i dziećmi ${ }^{61}$, alimentacyjnych są wzorowane na odpowiednich przepisach Brukseli I i II bis.

$\mathrm{Na}$ gruncie polskich norm kolizyjnych stosowanych w obszarach, w których nie doszło do ujednolicenia (za pomoca prawa unijnego lub umów międzynarodowych), decydujące znaczenie ma wciąż łącznik obywatelstwa małżonków (np.: zdolność zawarcia małżeństwa ${ }^{62}$, skutki zawarcia małżeństwa ${ }^{63}$, rozwiązania małżeństwa ${ }^{64}$ ) względnie dziecka (m.in. ustalenie i zaprzeczenie pochodzenia dziecka ${ }^{65}$, przysposobienie ${ }^{66}$ ). Łączniki miejsca zamieszkania oraz zwykłego pobytu maja zasadniczo pomocniczy charakter (m.in. skutki zawarcia małżeństwa ${ }^{67}$, rozwiązanie

${ }^{55}$ Sekcja $18-19$ i art. 6-7 Civil Jurisdicion and Judgments Act 1982.

${ }_{56}$ Dz.U. 2015, poz. 1792.

${ }^{57}$ Ustawa - Kodeks postępowania cywilnego z dnia 17 listopada 1964 r. Dz.U. 2018, poz. 1360 .

${ }^{58}$ Dz.Urz. UE L nr 12, 16.01.2001, s. 1-23.

${ }^{59}$ Ustawa z dnia 5 grudnia 2008 r. o zmianie ustawy - Kodeks postępowania cywilnego oraz niektórych innych ustaw. Dz.U. 2008, nr 234, poz. 1571, weszła w życie dnia 1 lipca 2009 r.

${ }^{60}$ Data rozpoczęcia stosowania rozporządzenia Parlamentu Europejskiego i Rady (UE) nr 1215/2012 z dnia 12 grudnia 2012 r. w sprawie jurysdykcji i uznawania orzeczeń sądowych oraz ich wykonywania w sprawach cywilnych i handlowych. Dz.Urz. UE L nr 351, 20.12.2012, s. 1-32, Bruksela I bis, które zastąpiło Brukselę I.

${ }^{61}$ Por. m.in. art. $1103^{2}$, art. $1103^{3}$, art. $1106^{3}$ k.p.c.

${ }^{62}$ Artykuł 48 p.p.m. 2011.

${ }^{63}$ Artykuł 51 ust. 1 p.p.m. 2011.

${ }^{64}$ Artykuł 54 ust. 1 p.p.m. 2011.

${ }_{65}$ Artykuł 55 p.p.m. 2011.

${ }_{66}$ Artykuł 57 p.p.m. 2011.

${ }^{67}$ Artykuł 51 ust. 2 p.p.m. 2011. 
małżeństwa ${ }^{68}$ ), przeciwnie do norm k.p.c. określajacych jurysdykcję krajową, wzorowanych na unijnych rozporządzeniach.

\section{Skutki prawne brexitu w zakresie transgranicznych spraw rodzinnych}

Brexit może oznaczać poważne zmiany źródeł prawa z uwagi na kres obowiązywania ujednoliconego w UE prawa prywatnego międzynarodowego, którego największą zaletą jest znoszenie wszelkich formalności i barier w zakresie dostępu do szeroko pojętego wymiaru sprawiedliwości. Na przykład orzeczenia sądowe w sprawach rodzinnych wydane $\mathrm{w}$ jednym państwie unijnym sa automatycznie uznawane $\mathrm{w}$ każdym innym państwie unijnym; z kolei ich wykonanie może przebiegać dwutorowo: po wcześniejszym stwierdzeniu wykonalności w odrębnym postępowaniu (np. brytyjskie orzeczenia alimentacyjne w Polsce) albo automatycznie bez potrzeby podejmowania jakichkolwiek działań poprzedzajacych samo wykonanie (np. polskie orzeczenia alimentacyjne w Wielkiej Brytanii).

Eksperci zajmujący się prawem prywatnym międzynarodowym wskazuja jednak, że transgraniczne sprawy rodzinne nie znajda się wysoko na liście priorytetów politycznych związanych z brexitem ${ }^{69}$. Rodzi to obawy dotyczace pewności i przewidywalności prawa, co jest bardzo niepokojące dla rodzin międzynarodowych. Jednocześnie zwraca się uwagę, że UK po opuszczeniu UE, „otoczone” przez państwa członkowskie UE, nie będzie mogło odizolować się od unijnej polityki PWBS, biorąc pod uwagę globalizację oraz dużą mobilność ludzi, straci jednak jakikolwiek wpływ na treść i zakres tej polityki, jaki daje udział w strukturach $\mathrm{UE}^{70}$.

Zjednoczone Królestwo po opuszczeniu struktur unijnych stanie się dla UE krajem trzecim. Brexit oznacza koniec zasady swobodnego przepływu na terenie UK, która sprzyjała i chroniła mobilność w UE pracowników, osób prowadzących działalność na własny rachunek, usługodawców, studentów, emerytów i inne osoby, w tym członków rodziny

68 Artykuł 54 ust. 2 p.p.m. 2011.

69 Brexit and Family Law, October 2017, Family Law Bar Association (FLBA), International Academy of Family Lawyers (IAFL), https://www.resolution.org.uk [Dostęp: 17.02.2020 r.], s. 20.

70 D. Curtin: The ties that bind..., s. 155. 
z krajów trzecich, od prawie 50 lat $^{71}$. Stworzenie nowego reżimu prawnego po brexicie dla osób przemieszczających się jest zadaniem bardzo złożonym z powodu zawiłości istniejącego prawa UE w tej dziedzinie ${ }^{72}$.

\subsection{W poszukiwaniu najlepszego rozwiązania}

Jedna z pierwszych propozycji rozważanych przez stronę brytyjska było przyjęcie, że prawo unijne obowiązujące bezpośrednio w UK przed datą brexitu stanie się częścia prawa wewnętrznego po dacie brexitu ${ }^{73}$. $\mathrm{W}$ założeniu miało to być rozwiazanie tymczasowe, które pozwoliłoby parlamentom brytyjskim na decydowanie o tym, jaki dorobek prawny każdy z nich chce przyjać i dostosować za pomoca krajowego prawa wtórnego $^{74}$. W zakresie prawa prywatnego międzynarodowego pomysł ten szybko spotkał się z krytyką. Rozporządzenia unijne dotyczące jurysdykcji oraz skuteczności zagranicznych orzeczeń wymagają bowiem wzajemności oraz zaufania przy ich stosowaniu ${ }^{75}$. Zatem sady brytyjskie byłyby jednostronnie zobowiązane do uznawania i wykonywania orzeczeń pochodzacych z państw unijnych, gdy tymczasem sądy państw członkowskich UE nie miałyby takiego obowiązku w stosunku do orzeczeń brytyjskich $^{76}$. W takiej sytuacji istniałoby znaczne ryzyko prowadzenia równoległych postępowań w UK i innych państwach członkowskich UE, a w konsekwencji wielość wyroków oraz trudności z pogodzeniem ich treśsi ${ }^{77}$. Zdaniem brytyjskich ekspertów, jest to najgorsze z możliwych rozwiązań, postawiłoby bowiem obywateli brytyjskich w gorszej sytuacji niż sytuacja obywateli Unii, pogłębiłoby stan niepewności prawnej oraz

${ }^{71} \mathrm{O}$ możliwych modelach relacji Wielkiej Brytanii z Unią Europejską z perspektywy swobody przepływu osób por. S. Kubas: Brexit a swoboda przepływu osób z polskiej perspektywy. W: Unia Europejska w przededniu Brexitu. Red. J. Barcik, M. Półtorak. Warszawa 2018, s. 158.

72 J. Shaw: Citizenship and free movement in a changing EU: Navigating an archipelago of contradictions. In: Brexit and Beyond... Eds. B. Martill, U. Staiger, doi: 10.2307/j.ctt20krxf8, https://www.jstor.org/stable/j.ctt20krxf8, s. 157.

${ }^{73}$ European Union (Withdrawal) Bill 2017; services.parliament.uk bills/2017-19/ europeanunionwithdrawal.html. Szerzej na ten temat J. Gumuła-Kędracka: Brexit a reforma rozporzadzenia Bruksela II bis. W: Unia Europejska w przededniu Brexitu. Red. J. Barcik, M. Półtorak..., s. 179.

${ }^{74}$ J. Fitchen: The Private International Law Consequences of Brexit. „Nederlands Internationaal Privaatrecht" 2017, no. 3, s. 418.

${ }^{75}$ N. Lowe: Some reflections on the options for dealing with international family law following Brexit. „Family Law” 2017, vol. 399, s. 405; J. Fitchen: The Private International Law..., s. 418-419.

${ }^{76}$ M. Doyle: The impact of Brexit..., s. 17 i powołana tam literatura.

77 Brexit and Family Law..., s. 6. 
doprowadziłoby do niesprawiedliwych rozstrzygnięć ${ }^{78}$. Może to, zwłaszcza na początku, prowadzić do przewlekłości postępowań prowadzonych przed sądami brytyjskimi, a tym samym opóźnień w wydaniu rozstrzygnięcia z powodu niepewności prawnej, a zatem do zwiększenia kosztów postępowania $^{79}$.

Dodatkowo w przypadku zmiany w prawie unijnym po dacie brexitu brak nowelizacji w systemach prawych UK będzie oznaczać stosowanie prawa unijnego $\mathrm{w}$ dotychczasowym brzmieniu, tj. obowiązującego $\mathrm{w}$ dacie brexitu, a w konsekwencji brak jednolitości w transgranicznych sprawach rodzinnych między UK a państwami unijnymi. Takie zagrożenie dotyczy np. nowego rozporządzenia ${ }^{80}$, które ma zastąić Brukselę II bis. Nowe rozporządzenie będzie stosowane od 1 sierpnia 2022 r., co oznacza, że uchyli ono rozporządzenie Bruksela II bis dopiero 1 sierpnia $2022 \mathrm{r}^{81}$

$\mathrm{W}$ związku z poważnymi wadami koncepcji przeniesienia prawa unijnego do systemów prawnych UK konieczne stało się poszukiwanie innych propozycji rozwiązań, mających zapewnić pozostanie UK częścia jednolitego unijnego prawa prywatnego międzynarodowego w sprawach rodzinnych. Większość przedstawicieli doktryny i praktyki w UK za najlepsze rozwiązanie uważa utrzymanie między UK a UE, po opuszczeniu przez Zjednoczone Królestwo struktur unijnych, pełnej wzajemności w zakresie prawa rodzinnego ${ }^{82}$. Pozwoliłoby to skutecznie utrzymać obecny system i zachować w UK wszystkie jego korzyści, przede wszystkim zharmonizowane w całej UE regulacje dotyczące jurysdykcji do rozpatrywania spraw transgranicznych, uznawania i egzekwowania orzeczeń oraz współpracy transgranicznej ${ }^{83}$. Jednocześnie zaleca się - podobnie jak w przypadku Danii - pozostawienie dotychczasowej roli orzecznictwu TSUE. Jednak od początku prac majacych na celu opuszczenie UE rząd UK wyraźnie wykluczał poddanie się jurysdykcji TSUE w jakimkolwiek zakresie.

${ }^{78}$ Ibidem.

${ }^{79}$ Ibidem.

${ }^{80}$ Rozporządzenie Rady (UE) 2019/1111 z dnia 25 czerwca 2019 r. w sprawie jurysdykcji, uznawania i wykonywania orzeczeń w sprawach małżeńskich i w sprawach dotyczących odpowiedzialności rodzicielskiej oraz w sprawie uprowadzenia dziecka za granicę. Dz.Urz UE L nr 178, 2.07.2019, s. 1-115, https://eur-lex.europa.eu/legal-content/pl/ TXT/?uri=CELEX:32019R1111 [Dostęp: 26.07.2019 r.] uchyla przepisy dotychczasowej Brukseli II bis (art. 140), stosuje się od 1 sierpnia $2022 \mathrm{r}$.

${ }^{81}$ Artykuł 104 ust. 2 nowej Brukseli II bis.

${ }^{82}$ Por. Resolution „The implications of Brexit for the justice system - written evidence by Resolution to the Justice Select Committee" (2017), annexed to The Law Society Meeting Paper 18th July 2017 (n 62) point 4; szerzej por. M. Doyle: The impact of Brexit..., s. 18 i powołaną tam literaturę; Brexit and Family Law..., s. 6.

83 Ibidem. 
Kolejnym branym pod uwagę rozwiązaniem, poważnie rozważanym przez brytyjskich polityków na początku $2017 \mathrm{r} .{ }^{84}$, było zawarcie indywidualnie uzgodnionej umowy z UE, która określałaby nowe ramy współpracy $\mathrm{w}$ zakresie prawa rodzinnego między Wielką Brytania a UE. Eksperci wskazuja jednak, że jest to mało realistyczne, ponieważ opracowanie, wynegocjowanie i wprowadzenie alternatywnych rozwiązań jest tak czasochłonne, że nie będzie możliwe do dnia zakończenia okresu przejściowego (do 31 grudnia 2020 r. . $^{85}$.

Jednak niektórzy przedstawiciele doktryny twierdzili, że nie jest konieczne ani „zatrzymanie” prawa unijnego, ani umowa między UK a UE gwarantująca pełne respektowanie przez obie strony zasady wzajemności, ponieważ lukę po prawie unijnym wypełnia konwencje haskie opracowane pod auspicjami $\mathrm{HCCH}^{86}$, a w przypadku państw niebędacych ich stronami - umowy dwustronne ${ }^{87}$. Rozwiazanie to zakłada, że UK powróci do stosowania już istniejących instrumentów prawnych natychmiast, gdy rozporządzenia UE przestaną obowiązywać88, co pozwoli uniknąć „próż-

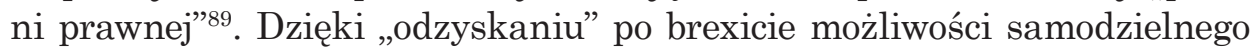
zawierania umów międzynarodowych z państwami trzecimi ${ }^{90}$, dotychczas niemożliwej z uwagi na wyłącznie zewnętrzne kompetencje UE w sprawach regulowanych przez wtórne unijne prawo, UK może także zawierać nowe konwencje w celu wypełnienia luki po unijnym p.p.m. Problem w tym, że państwa członkowskie nie mogą zawierać takich umów z państwami trzecimi (czyli z UK po zakończeniu okresu przejściowego).

Koncepcja powrotu do stosowania konwencji haskich („odżycia”) dotyczacych spraw rodzinnych opiera się na podobieństwie treści tych konwencji do treści rozporządzeń unijnych. Trzeba jednak pamiętać, że regulacje haskich konwencji oraz opartych na nich unijnych rozporządzeń $\mathrm{w}$ transgranicznych sprawach rodzinnych nie sa identyczne, ponieważ

${ }^{84}$ House of Lords European Union Select Committee: Brexit: justice for families, individuals and businesses?, 20 March 2017, HL Paper 134, https://www.publica tions.parliament.uk/pa/ld201617/ldselect/ldeucom/134/13402.htm, s. 39/139 [Dostęp: 24.07.2019 r.].

${ }_{85}$ Brexit and Family Law..., s. 7. Por. propozycje zawarte w Białej Księdze w sprawie brexitu: The United Kingdom's exit from and new partnership with the European Union (HM Government, 2017), pkt 12.2 .

${ }^{86}$ P. Beaumont: Private international law concerning children in the UK after Brexit: comparing Hague Treaty Law with EU Regulations, www.abdn.ac.uk/law/docu ments/CPIL\%20Working\%20Paper\%20No\%202017_2.pdf [Dostęp: 2.07.2019 r.].

${ }^{87}$ „Law Society Meeting Paper” 18 July 2017; M. Doyle: The impact of Brexit..., s. 36 .

${ }^{88}$ P. Beaumont: Private international law..., s. 3.

${ }^{89}$ W UK określane jako cliff-edge.

90 J. Fitchen: The Private International Law..., s. 19. 
prawo unijne wprowadziło zmiany i nowe rozwiązania istotne zwłaszcza z perspektywy dziecka ${ }^{91}$, oceniane na ogół jako korzystniejsze dla dziec$\mathrm{ka}^{92}$. Z tego powodu powrót do konwencji haskich bywa określany jako dobrowolna rezygnacja $\mathrm{z}$ „wartości dodanej” prawa $\mathrm{UE}^{93}$. Jednak zmiany wprowadzone przez prawo unijne, które w zamierzeniu miały poprawić sytuację prawną dziecka, opierając się na doświadczeniach związanych ze stosowaniem konwencji haskich, nie zawsze można uznać za korzystniejsze. Można natomiast o nich powiedzieć, że miały na celu poprawę współpracy sądowej w transgranicznych sprawach rodzinnych. Ponadto zakres prawa unijnego jest szerszy niż zakres konwencji haskich (np. Bruksela II bis reguluje także jurysdykcję w sprawach rozwodu, separacji i unieważnienia małżeństwa).

Dostrzega się także pewne obawy, związane z płynnym przejściem do stosowania konwencji haskich ${ }^{94}$, a konkretnie „problemy techniczne związane z przystapieniem Wielkiej Brytanii do odpowiednich konwencji” ${ }^{95}$. Pojawiły się one w związku z opinia TSUE $1 / 13^{96}$, wydaną na tle haskiej Konwencji dotyczacej cywilnych aspektów uprowadzenia dziecka za granicę ${ }^{97}$. W świetle tej opinii wyrażenie zgody na przystąpienie państwa trzeciego do wspomnianej Konwencji należy do wyłącznej kompetencji UE. Oznacza to, że państwo członkowskie UE nie może samodzielnie złożyć oświadczenia o wyrażenie zgody na przystąpienie państwa trzeciego do konwencji haskiej z 1980 r., ponieważ musi mieć na to zgode Komisji Europejskiej. Powodem przyjęcia takiego stanowiska jest fakt, że konwencja haska z 1980 r. nie daje regionalnej organizacji integracji europejskiej, przykładem której jest UE, możliwości złożenia oświadczenia o wyrażeniu zgody na przystąienie innego państwa do

${ }^{91}$ M. Doyle: The impact of Brexit..., s. 18 i powołana tam literatura.

92 Takie różnice i ich wpływ na sytuacje dziecka - pokazujące, że nie zawsze sa to zmiany korzystniejsze dla dziecka - na przykładzie Brukseli II bis oraz Konwencji haskiej o cywilnych aspektach uprowadzenia dziecka za granicę 1980 r. oraz Konwencji haskiej o jurysdykcji, prawie właściwym, uznawaniu, wykonywaniu i współpracy w zakresie odpowiedzialności rodzicielskiej oraz środków ochrony dzieci z 1996 r., por. J. Gumuła-Kędracka: Brexit a reforma..., s. 180-182.

${ }_{93}$ M. Doyle: The impact of Brexit..., s. 18.

${ }^{94}$ Brexit and Family Law..., s. 17; por. M. Pilich: Brexit and EU private international law..., s. 8-13 i powołaną tam literaturę.

${ }^{95}$ M. Doyle: The impact of Brexit..., s. 18.

${ }_{96}$ Opinia Trybunału 1/13 (wielka izba) z dnia 14 października 2014 r. ECLI: EU:C:2014:2303, krytykowana w doktrynie m.in. za zbytnie ingerowanie w suwerenność państw członkowskich, niezgodność z celami traktatów unijnych, zob. P. Beaumont: A Critical Analysis of the Judicial Activism of the Court of Justice of the European Union in Opinion 1/13. In: The External Action of the EU in the Field of Private International Law after Opinion 1/13. Ed. P. Franzina. Intersentia 2016, s. 55-74.

${ }_{97}$ Dz.U. 1995, nr 108, poz. 528. 
wskazanej konwencji ${ }^{98}$. Oświadczenie takie może wyrazić jedynie państwo jako suwerenny podmiot prawa międzynarodowego publicznego. Dopiero na skutek przystąpienia UE do grona członków HCCH w 2005 r. oraz związanej z tym zmiany statutu HCCH regionalne organizacje integracji europejskiej uzyskały zdolność traktatową, dotychczas zarezerwowaną wyłącznie dla suwerennego państwa ${ }^{99}$. Zatem w odniesieniu do konwencji haskich przyjętych po 2005 r. może do nich przystapić UE, a także ewentualnie do konwencji przyjętych wcześniej, jeśli dojdzie do zmiany ich postanowień, czego dotychczas nie praktykowano.

W odniesieniu jednak do Konwencji haskiej dotyczacej cywilnych aspektów uprowadzenia dziecka za granicę oraz Konwencji haskiej o jurysdykcji, prawie właściwym, uznawaniu, wykonywaniu i współpracy w zakresie odpowiedzialności rodzicielskiej oraz środków ochrony dzieci z 1996 r. ${ }^{100}$ obawy wynikające z opinii TSUE $1 / 13$ sa bezzasadne, ponieważ UK złożyło stosowne deklaracje przystąpienia do nich jako członek $\mathrm{HCCH}$, a nie jako członek $\mathrm{UE}^{101}$. Brexit zatem w żaden sposób nie wpłynie na obowiązywanie tych konwencji w prawie międzynarodowym nie tylko w odniesieniu do UK, ale także innych państw będących ich stronami, które do nich przystąpiły samodzielnie, a nie jako członkowie UE.

Sytuacja jest jasna w odniesieniu do konwencji z 1980 r., jednak faktem jest, że konwencja z 1996 r. obowiązuje w UK na podstawie European Communities Act 1972. Wprawdzie UK podpisało tę konwencję 1 kwietnia 2003 r., lecz została ona ratyfikowana i weszła w życie dopiero w 2010 r., dokładnie w tych samych datach, w których została ratyfikowana i weszła w życie w UE, a więc powinna być w UK traktowana jako instrument unijny ${ }^{102}$. Jako uzasadnienie takiego działania podaje się chęć ratyfikacji konwencji z 1996 r. bez potrzeby wydawania ustawy krajowej, koniecznej do obowiązywania konwencji w brytyjskim systemie prawnym, a dokładnie kilku ustaw krajowych, skoro na system prawny Zjednoczonego Królestwa składa się system prawny Anglii, Walii, Szkocji i Irlandii Północnej. Zatem uchylenie po zakończeniu okresu przejściowego European Communities Act 1972, dzięki któremu zaczęto stosować w UK konwencję haską z 1996 r., może oznaczać niepewność co do jej

${ }^{98}$ P. Beaumont: Private international law..., s. 1.

99 Artykuł 3 jednolitego zmienionego Statutu Haskiej Konferencji Prawa Prywatnego Międzynarodowego, przyjęty w Hadze dnia 30 czerwca 2005 r. (Dz.U. 2013, poz. 1090), w języku angielskim https://www.hcch.net/en/instruments/conventions/fulltext [Dostęp: 7.07.2019 r.].

100 Dz.U. 2010, nr 172, poz. 1158.

${ }^{101}$ P. Beaumont: Private international law..., s. 2.

${ }_{102}$ M. Doyle: The impact of Brexit..., s. 32. 
statusu prawnego. W tym przypadku konieczne będzie wydanie ustawy będącej podstawą obowiązywania konwencji z 1996 r. ${ }^{103}$

Natomiast porównując treść Brukseli II bis z treścia konwencji haskiej z 1980 r. — w dużym skrócie — można wskazać, że Bruksela II bis przewiduje szybsze procedury w przypadku uprowadzenia dziecka oraz daje ostateczny głos $\mathrm{w}$ sprawie sadowi poprzedniego miejsca stałego pobytu dziec$\mathrm{ka}^{104}$. Z kolei konwencja haska z 1996 r., podobnie jak konwencja lugańska z 2007 r., nie przewiduje automatycznego wykonywania orzeczeń dotyczacych prawa do kontaktów z dzieckiem i niektórych orzeczeń pociągających za sobą powrót dziecka (art. 40 Brukseli II bis). Podobnie konwencja haska o uznawaniu rozwodów i separacji z 1970 r. nie może stanowić wystarczajacej alternatywy ${ }^{105}$ dla Brukseli II bis, ponieważ nie zawiera ona przepisów dotyczących jurysdykcji, co oznacza powrót do krajowych przepisów dotyczacych jurysdykcji, nie przewiduje także automatycznego uznawania i wykonywania orzeczeń rozwodowych. W praktyce oznacza to wydłużenie postępowań rozwodowych, a co za tym idzie większe koszty sądowe.

Jeszcze inaczej jest w przypadku Konwencji haskiej o międzynarodowym dochodzeniu alimentów z 2007 r., którą UK związało się na podstawie decyzji Rady z 2011 r. w sprawie zatwierdzenia wspomnianej konwencji ${ }^{106}$. UK przystapiło do niej jako członek UE. W związku z brexitem w dniu 28 grudnia 2018 r. UK samodzielnie ratyfikowało tę konwencję, by mogła ona wejść (ponownie) w życie dokładnie następnego dnia po dniu brexitu, pierwotnie 1 kwietnia 2019 r., po pierwszej planowanej dacie brexitu. Na skutek dwukrotnego przekładania ostatecznego terminu opuszczenia UE przez UK wstrzymano procedury ratyfikacji konwencji z 2007 r., najpierw do 13 kwietnia lub 23 maja 2019 r. (pierwsze przesunięcie daty brexitu), później do 1 listopada 2019 r. (drugie przesunięcie daty brexitu $)^{107}$. Po brexicie Ministerstwo Spraw Zagranicznych UK wycofało się $\mathrm{z}$ ratyfikacji obu konwencji $\mathrm{w}$ okresie przejściowym, zapowiadając ponowna ratyfikację po jego zakończeniu ${ }^{108}$. Jak widać, oficjalnie kroki podjęte zostały jedynie odnośnie do dwóch wyżej wymienionych konwencji, co wskazuje na częściowe poparcie dla koncepcji stosowania niektórych konwencji haskich po brexicie.

${ }^{103}$ Ibidem; N. Lowe: Some reflections..., s. 405.

${ }^{104}$ Brexit and Family Law..., s. 18.

${ }^{105}$ Ibidem.

106 Decyzja Rady z dnia 9 czerwca 2011 r. w sprawie zatwierdzenia w imieniu Unii Europejskiej Konwencji haskiej z dnia 23 listopada 2007 r. o międzynarodowym dochodzeniu alimentów na rzecz dzieci i innych członków rodziny. Dz.Urz. UE L nr 192, 2011, s. 39.

107 Stosowne komunikaty zamieszczone na stronie https://www.hcch.net/en/instru ments/conventions/status-table/notifications/?csid=1255\&disp=resdn [Dostęp: 3.07 .2019 r.].

$108 \mathrm{https}: / / \mathrm{ww}$.hcch.net/en/instruments/conventions/status-table/notifications/?csid $=1255 \&$ disp=resdn [Dostęp: 20.03.2020 r.]. 
Mimo to pojawiły się wątpliwości, czy w świetle opinii TSUE 1/13 stosowanie Konwencji haskiej o międzynarodowym dochodzeniu alimentów z 2007 r. po brexicie w relacjach z państwami unijnymi nie będzie jednak wymagało zgody Komisji ${ }^{109}$. Intensywnie tworzona w ciagu ostatnich kilkunastu lat sieć wzajemnych powiązań między unijnym prawem prywatnym międzynarodowym a systemem konwencji haskich opracowanych przez HCCH utrudnia automatyczny powrót do stosowania konwencji haskich. Multicentryczność systemów prawnych jest więc swoistą pułapka.

W porównaniu z rozporządzeniem nr 4/2009 konwencja haska z 2007 r. nie reguluje jurysdykcji ani automatycznego uznawania i wykonywania orzeczeń. Inaczej także niż rozporządzenie przewiduje możliwość składania zastrzeżeń ${ }^{110}$. Ich działanie może polegać na wyłączeniu niektórych postanowień konwencji w odniesieniu do państwa je składajacego lub odwrotnie - na rozszerzaniu zakresu jej zastosowania. Dzięki możliwości składania zastrzeżeń konwencja z 2007 r. jest elastyczna, co jednak nie sprzyja jednolitości jej stosowania, ponieważ w poszczególnych państwach moga obowiazywać różne wersje jednej konwencji.

W kontekście różnych rozwiązań po brexicie często zwraca się również uwagę na Konwencję lugańską z 2007 r. o jurysdykcji i uznawaniu oraz wykonywaniu orzeczeń sadowych w sprawach cywilnych i handlowych [dalej: konwencja lugańska z 2007 r.], którą UK związało się jako członek UE ${ }^{111}$. Konwencja lugańska z 2007 r. rozszerza zakres zastosowania Brukseli I sprzed przekształcenia na państwa EFTA. Pozostanie UK poza reżimem konwencji lugańskiej z 2007 r. oceniano jako „wielki krok wstecz w dostępie do wymiaru sprawiedliwości" ${ }^{112}$, dlatego też rząd brytyjski zapowiedział przystapienie do konwencji lugańskiej z 2007 r. po zakończeniu okresu przejściowego ${ }^{113}$. Konwencja lugańska z $2007 \mathrm{r}$. jest typem konwencji półotwartej. Moga do niej bez żadnych ograniczeń przystąpić państwa EFTA, a każde inne państwo ${ }^{114}$ - wyłącznie na zaproszenie depozytariusza (po uzyskaniu jednomyślnej zgody wszystkich

${ }^{109}$ Bar Council Brexit Working Group; por. M. Doyle: The impact of Brexit..., s. 31.

${ }_{110}$ Brexit and Family Law..., s. 17.

${ }^{111}$ UK jest jej stroną od pierwszego dnia zatwierdzenia konwencji przez UE, por. pkt 10 preambuły, decyzja Rady z dnia 27 listopada 2008 r. dotycząca zawarcia Konwencji o jurysdykcji i uznawaniu oraz wykonywaniu orzeczeń sądowych w sprawach cywilnych i handlowych (2009/430/WE). Dz.Urz. UE L 147, 10.06.2009, s. 1-4.

112 „a huge step back for access to justice”; por. E. Lein: Litigation post Brexit, s. 3, https://www.biicl.org/documents/1532_faq_-_litigation_post_brexit.pdf?showdocu ment=1 [Dostęp: 15.07.2019 r.].

${ }^{113}$ Pozwoli to „zastapić” Brukselę I w relacjach UK - UE i EFTA; J. Fitchen: The Private International Law..., s. 432.

${ }^{114}$ Dlatego pojawiają się głosy, że aby przystąić do konwencji lugańskiej z 2007 r., UK będzie musiało przystapić do EFTA; Brexit and Family Law..., s. 17. 
umawiających się państw), a wchodzi ona w życie wyłącznie pomiędzy państwem przystępującym oraz tymi umawiającymi się stronami, które nie wniosły żadnego sprzeciwu wobec przystapienia (art. 70 ust. 1 lit. a i c, art. 72 konwencji z 2007 r.). Aktualnie UK otrzymało deklaracje poparcia od Norwegii, Islandii i Szwajcarii, wymagana jest jeszcze zgoda $\mathrm{UE}^{115}$. Zatem sprawa ratyfikacji konwencji lugańskiej wydaje się pewna.

Jeśli chodzi o sprawy rodzinne, konwencja lugańska z 2007 r. dotyczy jedynie spraw alimentacyjnych, a wyraźnie wyłącza spod zakresu zastosowania sprawy stanu cywilnego (art. 1 ust. 2 lit. a). Jest więc remedium na brak regulacji jurysdykcji oraz automatycznego uznawania orzeczeń $\mathrm{w}$ sprawach alimentacyjnych w konwencji haskiej o dochodzeniu alimentów z 2007 r., ale nie zrekompensuje utraty Brukseli II bis ${ }^{116}$. Biorąc pod uwagę skuteczność zagranicznych orzeczeń, nie jest również tak nowoczesna, jak Bruksela II bis oraz rozporządzenie 4/2009, które przewiduja automatyczne wykonywanie orzeczeń, bez potrzeby stwierdzania wykonalności w przypadku niektórych orzeczen ${ }^{117}$.

Wprawdzie kraje EFTA nie podlegają jurysdykcji TSUE, zgodnie jednak z art. 1 protokołu 2 konwencji lugańskiej dotyczacego jednolitej wykładni konwencji, sądy ją stosujące i dokonujące jej wykładni zobowiązane sa uwzględnić zasady wynikające z orzeczeń dotyczących jej postanowień, wydanych przez sądy każdego państwa będącego jej stroną oraz wydanych przez TSUE. Zatem dalsze obowiązywanie konwencji lugańskiej z $2007 \mathrm{r}$. w Wielkiej Brytanii oznacza konieczność stosowania orzecznictwa TSUE.

Z kolei w kierunku wykorzystania modelu współpracy między UE a Dania ida propozycje zawarcia przez UK z UE umowy podobnej do tej, jaka zawarła Dania ${ }^{118}$ w sprawie stosowania rozporządzenia Bruksela $I^{119}$, uchylonego i zastąpionego rozporządzeniem Bruksela I bis ${ }^{120}$.

$115 \mathrm{https} / / / \mathrm{www}$.gov.uk/government/news/support-for-the-uks-intent-to-accede-tothe-lugano-convention-2007 [Dostęp: 20.02.2020 r.].

116 J. Gumuła-Kędracka: Brexit a reforma..., s. 184.

117 Zob.: art. 41-42 Brukseli II bis (orzeczenia dotyczace prawa do kontaktów z dzieckiem i powrotu dziecka), art. 17 ust. 2 rozporządzenia nr 4/20009, art. 38 konwencji lugańskiej z 2007 r.; por. Brexit and Family Law..., s. 17.

118 Umowa pomiędzy Unią Europejską a Królestwem Danii w sprawie właściwości sądów oraz uznawania i wykonywania orzeczeń sądowych w sprawach cywilnych i handlowych. Dz.Urz. UE L nr 299, 16.11.2005, s. 62; decyzja Rady 2006/325/WE z dnia 27 kwietnia 2006 r. dotycząca zawarcia umowy pomiędzy Wspólnotą Europejską a Królestwem Danii w sprawie właściwości sądów oraz uznawania i wykonywania orzeczeń sądowych w sprawach cywilnych i handlowych. Dz.Urz. UE L nr 120, 5.05.2006, s. 22.

119 Rozporządzenie Rady (WE) nr 44/2001 z dnia 22 grudnia 2000 r. w sprawie jurysdykcji i uznawania orzeczeń sądowych oraz ich wykonywania w sprawach cywilnych i handlowych. Dz.Urz. UE L nr 12, 16.01.2001, s. 1 [dalej: Bruksela I].

${ }^{120}$ Rozporządzenie Parlamentu Europejskiego i Rady (UE) nr 1215/2012 z dnia 12 grudnia 2012 r. w sprawie jurysdykcji i uznawania orzeczeń sądowych oraz ich wyko- 
Dodatkowo zakres takiej umowy proponuje się rozszerzyć o sprawy regulowane przez Brukselę II bis oraz rozporządzenie nr 4/2009121. Taka umowa mogłaby wypełnić lukę po utracie rozporządzeń Bruksela I bis, Bruksela II bis, rozporządzenia nr 4/2009 oraz konwencji lugańskiej z 2007 r. w relacjach z państwami EFTA. Analogicznie do konwencji lugańskiej z 2007 r., taka umowa oznaczałaby dla UK akceptowanie orzecznictwa TSUE, gdyż zdaniem przedstawicieli nauki i praktyki, dzisiaj jedynie jednolita wykładnia TSUE pozwala zapewnić rozstrzygnięciom międzynarodowa harmonię ${ }^{122}$. Propozycja ta nie spotkała się jednak z oficjalnym poparciem.

Inną propozycja jest „partnerstwo kontynentalne” między UE a UK $\mathrm{w}$ dziedzinie prawa prywatnego międzynarodowego ${ }^{123}$. Jest ona oparta na istniejacym modelu współpracy UK - UE w zakresie prawa prywatnego międzynarodowego. Z założenia każda ze stron partnerstwa (UE jako całość i UK) może przedstawić wnioski ustawodawcze. Dzięki temu UK oraz państwa UE mogłyby pracować nad poprawą i rozwojem nowych unijnych instrumentów prawa prywatnego międzynarodowego ${ }^{124}$. Podstawowa zaleta partnerstwa to możliwości łatwego przekształcenia rozporządzeń w umowy międzynarodowe, które maja zostać przyjęte w relacjach UE - UK i odwrotnie. Ponadto partnerstwo kontynentalne nie powinno być postrzegane jako konkurencja dla $\mathrm{HCCH}$.

Jednak - realistycznie rzecz ujmujac — obecna europejska polityka legislacyjna nie jest spójna nawet w odniesieniu do krajów UE, którym nie przyznano specjalnego statusu porównywalnego z Wielką Brytania, Irlandią lub Danią. Nie wróży to dobrze współpracy sądowej w sprawach cywilnych $^{125}$. Wydaje się, że UE nie zdoła poprawić niedoskonałości wynikającej z nadmiaru regulacji prawnych ${ }^{126}$.

nywania w sprawach cywilnych i handlowych. Dz.Urz. UE L 351, 20.12.2012, s. 1-32, stosuje się od 10 stycznia 2014 r.; pismem z dnia 20 grudnia 2012 r. Dania powiadomiła Komisję o swojej decyzji w sprawie wdrożenia treści rozporządzenia (UE) nr 1215/2012. Dz.Urz. UE L nr 149, 12.06.2009, s. 80.

${ }^{121}$ E. Lein: Litigation..., s. 3.

${ }^{122}$ Ibidem, s. 4.

${ }^{123}$ M. Pilich: Brexit and EU..., s. $16-17$ i powołana tam literatura.

${ }^{124}$ J. Pisani-Ferry et al.: Europe after Brexit: A proposal for a continental partnership. Bruegel 2016.

${ }^{125}$ "Centralization of European private international law in less than two decades after the Treaty of Amsterdam has been dramatic". R.A. Brand: Implementing the 2005 Hague Convention: The EU Magnet and the US Centrifuge. „Legal Studies Research Paper Series: Working Paper" no. 2013—20 (2013), http://ssrn.com/abstract¹/42288708.

${ }^{126}$ Por. wezwanie do większej spójności między różnymi rozporządzeniami UE dotyczacymi prawa prywatnego międzynarodowego jest oceniane jako nierealistyczne w czasie kryzysu politycznego w UE; por. R. Wagner: Do We Need a Rome 0 Regulation? „Netherlands International Law Review” 2014/61, s. 225. 


\subsection{Brak jednolitej interpretacji}

Jedną z zalet prawa UE jest to, że jest ono stosowane jednolicie w całej Unii, dzięki wykładni dokonywanej przez TSUE. Niezależnie od przyjętego rozwiazania w rodzinnych sprawach transgranicznych brexit niesie ryzyko braku tej jednolitości. System konwencji haskich z powodu braku organu sądowego podobnego do TSUE nie może zapewnić jednolitej interpretacji na takim poziomie, jak prawo unijne. Wprawdzie stosując konwencje haskie, sądy krajowe mogą uwzględniać orzeczenia sądów innych umawiających się stron, lecz takie orzeczenia zagraniczne nie są wiążące. Przykładem podejmowania starań w kierunku jednolitej wykładni sa tworzone przez HCCH internetowe bazy wyroków wydawanych w umawiających się państwach ${ }^{127}$. Dotyczy to szczególnie konwencji haskiej z 1980 r. o cywilnych aspektach uprowadzenia dziecka za granicę ${ }^{128}$.

Mimo to brak jednolitej interpretacji jest widoczny w wielu obszarach konwencji haskich, np. w odniesieniu do kluczowych pojęć, jak miejsce zwykłego pobytu ${ }^{129}$. Czasami interpretacja postanowień konwencji haskiej różniła się nawet między sądami w jednym umawiającym się państwie, np. w zakresie miejsca zwykłego pobytu w USA.

W dłuższej perspektywie „zatrzymanie” prawa unijnego w UK po brexicie niesie więc z soba ryzyko różnorodnej interpretacji prawa. Interpretacje tych przepisów, identyczne $\mathrm{z}$ interpretacjami przepisów prawa unijnego w pozostałych 27 państwach członkowskich, przez TSUE nie będa wiążące dla sądów brytyjskich ${ }^{130}$. Dlatego też system ochrony dzieci i rodziny oparty na konwencjach haskich uznaje się za mniej przewidywalny od systemu obowiązującego w $\mathrm{UE}^{131}$. Ponadto brak jednolitej interpretacji może także wystąpić pomiędzy różnymi systemami prawnymi UK. I tak w Szkocji nie obowiązuje Konwencja o prawach dziecka ${ }^{132}$, co oczywiście nie musi oznaczać niższego standardu ochrony dziecka.

Choć wyjście z UE nie stanowi automatycznego i całkowitego odcięcia się od orzecznictwa TSUE, tym bardziej przy „zatrzymaniu” prawa unij-

${ }^{127}$ Por. INCADAT, www.incadat.com, 5.07.2019 r.

${ }^{128}$ Dz.U. 1995, nr 108, poz. 528.

${ }^{129}$ M. Doyle: The impact of Brexit..., s. 33.

${ }^{130}$ Por. komentarze: D. Williams, R. Bailey Harris: Select Committee on the European Union Justice Sub-Committee Corrected oral evidence: Brexit: civil justice cooperation and the CJEU, s. 7-8, http://data.parliament.uk/writtenevidence/committeeevi dence.svc/evidencedocument/eu-justice-subcommittee/brexit-civil-justice-cooperation/ oral/44261.pdf [Dostęp: 5.07.2019 r.].

${ }^{131}$ M. Doyle: The impact of Brexit..., s. 33.

${ }^{132}$ Przyjęta przez Zgromadzenie Ogólne Narodów Zjednoczonych dnia 20 listopada 1989 r. 
nego, rząd brytyjski bardzo długo opowiadał się za całkowitym odejściem od orzecznictwa TSUE ${ }^{133}$. Powodem była obawa przed zbyt dużym wpływem orzecznictwa TSUE na merytoryczne prawo brytyjskie po brexicie. Dlatego odrzucano także propozycje przypisania orzecznictwu TSUE niewiążącego doradczego charakteru w praktyce sądów brytyjskich ${ }^{134}$. Tymczasem eksperci podkreślaja, że należy dokonać rozróżnienia między obszarami prawa, w których TSUE zajmuje się prawem merytorycznym (jak w prawie konsumenckim lub w prawie pracy), a tymi obszarami prawa, w których zajmuje się kwestiami proceduralnymi (jak w przypad$\mathrm{ku}$ prawa rodzinnego) ${ }^{135}$. Unijne regulacje $\mathrm{w}$ zakresie transgranicznych spraw rodzinnych nie sa regulacjami merytorycznymi. UE nie ma kompetencji w zakresie merytorycznego prawa rodzinnego. Moim zdaniem, nie można jednak całkowicie wykluczyć wpływu orzeczeń TSUE na merytoryczne prawo rodzinne obowiązujące $\mathrm{w}$ jednym $\mathrm{z}$ systemów prawnych UK. Wprawdzie rola TSUE $\mathrm{w}$ zakresie transgranicznego prawa rodzinnego jest inna niż w prawie konsumenckim, jednak należy mieć na względzie, że zjawisko materializacji prawa prywatnego międzynarodowego dotyczy szczególnie spraw rodzinnych, także w wymiarze procesowym, czego przykładem jest uwzględnienie najlepszego interesu dziecka na płaszczyźnie jurysdykcji ${ }^{136}$, uznawania i wykonywania orzeczeń ${ }^{137} \mathrm{w}$ zakresie odpowiedzialności rodzicielskiej oraz bezprawnego uprowadzenia dziecka, a także obowiązek wysłuchania dziecka ${ }^{138}$. W praktyce możemy także obserwować negatywne zjawisko wykorzystywania unijnych rozporządzeń dotyczacych prawa prywatnego międzynarodowego do wprowadzania „tylnymi drzwiami” jednolitych rozwiązań materialnych ${ }^{139}$.

${ }^{133}$ UK White Paper, The United Kingdom's exit from and new partnership with the European Union, 2.3, 2.8, A.20, https://assets.publishing.service.gov.uk/government/ uploads/system/uploads/attachment_data/file/589191/The_United_Kingdoms_exit_ from_and_partnership_with_the_EU_Web.pdf [Dostęp: 24.07.2019 r.].

${ }_{134}$ Por. komentarz D. Williams, R. Bailey-Harris: Select Committee..., s. 8.

${ }^{135}$ Brexit and Family Law..., s. 13.

136 Pkt. 12-13 preambuły, art. 12 Brukseli II bis.

${ }^{137}$ Artykuł 23 lit. a jako element klauzuli porządku publicznego, stanowiącej podstawę odmowy uznania orzeczenia.

${ }^{138}$ Artykuł 23 lit. b jako podstawa nieuznania orzeczeń odnoszacych się do odpowiedzialności rodzicielskiej, art. 41 ust. 2, art. 42 ust. 2 (wydanie świadectwa orzeczenia wydanego przez sąd pochodzenia jako warunek automatycznego wykonania w zakresie prawa do kontaktów z dzieckiem) Brukseli II bis. Punkt 19 preambuły do Brukseli II bis zwraca jednak uwagę, że wysłuchanie dziecka odgrywa ważną rolę w stosowaniu rozporządzenia, nie ma jednak na celu modyfikacji procedur krajowych stosowanych w zakresie odpowiedzialności rodzicielskiej.

${ }_{139}$ P. Mostowik, K. Sondel-Maciejewska: Materialnoprawne rezultaty unijnej wspótpracy sadowej w sprawach rodzinnych. W: Wspótczesne wyzwania prawa prywatnego międzynarodowego. Red. J. Poczobut. Warszawa 2013, s. 173-176, 181. 
Ostatecznie na zasadzie wyjątku dopuszczono możliwość uwzględnienia przez brytyjskie sądy orzecznictwa TSUE wydanego po zakończeniu okresu przejściowego w zakresie ważności, treści oraz skutków wszelkich „zatrzymanych” w systemach brytyjskich przepisów pochodzenia unijnego, pod warunkiem jednak, że jest to konieczne do rozpatrzenia danej sprawy (sekcja 6(2-6) European Union (Withdrawal) Act 2018).

\subsection{Rozwiązanie przyjęte w Furopean Union (Withdrawal) Act 2018 oraz European Union (Withdrawal Agreement) Act 2020}

European Union (Withdrawal) Act 2018 [dalej: EUWA 2018] ${ }^{140}$ to ustawa, która miała uchylić z dniem brexitu European Communities Act 1972 [dalej: ECA 1972] oraz — co ważniejsze — ustanowić wymóg zgody parlamentu na zawarcie umowy o wystapieniu (sekcja 13) ${ }^{141}$. Weszła ona w życie 31 stycznia 2020 r. Istotnych zmian w EUWA 2018 dokonano na podstawie ustawy parlamentu ${ }^{142}$ - European Union (Withdrawal Agreement) Act 2020 [dalej: EUWA 2020] ${ }^{143}$, wdrażajacej do prawa krajowego po brexicie postanowienia umowy o wystapieniu (Withdrawal Agreement $^{144}$ [dalej: umowa o wystąpieniu]). Były one konieczne z uwagi na luki i błędy dostrzeżone w EUWA 2018 w czasie przedłużającego się okresu opuszczania UE przez UK.

Jedna z pierwszych zmian wprowadzonych do EUWA 2018 (sekcja 1A) przez EUWA 2020 jest utrzymanie mocy obowiazującej ECA 1972 w okresie przejściowym (od 1 lutego 2020 r. do 31 grudnia 2020 r.), zwanym „the implementation period"145. Było to konieczne z uwagi na postanowienia części czwartej Transition umowy o wystapieniu. Początkiem okresu przejściowego jest konkretna data, tj. dzień następujący po dacie brexitu, czyli 1 lutego 2020 r., natomiast ostatni dzień tego okresu nazwany „IP [implementation period - A.J.] completion day” został

${ }^{140}$ UK Public General Acts 2018 c. 16, http://www.legislation.gov.uk/ukpga/2018/16/ contents/enacted [Dostęp: 23.07.2019 r.].

${ }^{141}$ Akt otrzymał zgodę królewską 26 czerwca 2018 r.

${ }^{142}$ Akt otrzymał zgodę królewską 23 stycznia 2020 r.

${ }^{143}$ UK Public General Acts 2020 c. 1, http://www.legislation.gov.uk/ukpga/2020/1/ contents/enacted [Dostęp: 23.07.2019 r.].

${ }^{144}$ Agreement on the withdrawal of the United Kingdom of Great Britain and Northern Ireland from the European Union and the European Atomic Energy Community. Dz.Urz. UE L nr 29, s. 7.

${ }_{145}$ Sekcja 1A (6) „the implementation period” means the transition or implementation period provided for by Part 4 of the withdrawal agreement and beginning with exit day and ending on IP completion day. 
wprawdzie zdefiniowany prawnie na dzień 31 grudnia 2020 r., jednak może on ulec zmianie $\mathrm{w}$ następstwie przedłużenia okresu przejściowe$\mathrm{go}^{146}$. Ponadto pozbawienie mocy ECA 1972 oznaczałoby de facto brak podstawy prawnej obowiazywania w UK prawa unijnego w okresie przejściowym. Nie może nią być umowa o wystapieniu regulująca relacje UK - UE po brexicie.

Ogólnie rzecz biorąc, EUWA 2018 (sekcja 2 Saving for EU-derived domestic legislation), aby zapewnić ciagłość prawna, gwarantuje „zatrzymanie" po brexicie ustawodawstwa krajowego wydanego na podstawie prawa unijnego. W rozumieniu sekcji 2(2) chodzi o akty wydane na podstawie sekcji 2(2) European Communities Act 1972, a także akty mające na celu ich wykonanie. Sa to przede wszystkim przepisy niestanowione przez parlamenty brytyjskie, które maja na celu wykonywanie obowiazków lub korzystanie z praw przysługujacych UK na mocy traktatów unijnych. Kompetencje do wydawania takich aktów należą do królowej lub - w praktyce częściej — do ministrów. EWUA 2020 zasadę „zatrzymania" rozszerza na okres przejściowy (sekcja 1B EUWA 2018). Jednak z perspektywy unijnego p.p.m. o wiele większe znaczenie mają postanowienia sekcji 3 EUWA 2018 Incorporation of direct EU legislation (właczenie bezpośrednio stosowanego prawa unijnego), w świetle której prawo unijne obowiązujące bezpośrednio przed brexitem stanie się częścią prawa krajowego w dniu brexitu oraz po nim ${ }^{147}$ (sekcja 3(1)). W rozumieniu tego przepisu „direct EU legislation” (por. sekcja 20(1) „Interpretation”) to m.in. wszelkie unijne rozporządzenia. Zakresy sekcji 2 i 3 sa zatem wyraźnie rozgraniczone, dotyczą bowiem innego rodzaju aktów prawnych unijnego pochodzenia. Sekcja 5(4) wyłącza wyraźnie spod zakresów zastosowania sekcji 2 i 3 postanowienia Karty praw podstawowych ${ }^{148}$. Postanowienia sekcji 3, jako jedne z nielicznych, będą stosowane po upływie okresu przejściowego; obowiązywanie w okresie przejściowym unijnego prawa, do którego odnosi się sekcja 3, wynika z umowy o wystąieniu.

Sekcja 5 EUWA 2018 („Exceptions to savings and incorporation”) odnosi się do zasady pierwszeństwa stosowania prawa unijnego $\mathrm{w}$ obliczu „zatrzymania” oraz „włączenia” prawa pochodzącego od UE do brytyjskich systemów prawnych. Wprawdzie zgodnie z sekcja 5(1), zasada nadrzędności prawa UE nie ma zastosowania do aktu prawnego przyjętego lub wydanego po brexicie, lecz wiąże w dalszym ciagu po tej dacie w zakresie interpretacji, zaniechania lub uchylenia każdej normy prawnej przyjętej przed dniem brexitu.

${ }^{146}$ Artykuł 132 umowy o wystąieniu w zw. z sekcja 37(2) EUWA 2020.

147 „Direct EU legislation, so far as operative immediately before exit day, forms part of domestic law on and after exit day".

${ }^{148}$ Karta praw podstawowych Unii Europejskiej. OJ C 326, 26.10.2012, s. 391-407. 
Z kolei zgodnie z sekcją 6(1) EUWA 2018, dotyczaca interpretacji „zatrzymanego" prawa unijnego, sądy brytyjskie nie są związane żadnymi ustalonymi zasadami ani żadnymi decyzjami podjętymi po zakończeniu okresu przejściowego przez TSUE, nie moga także skierować żadnej sprawy do TSUE dnia następnego po zakończeniu okresu przejściowego. Jednakże moga one uwzględnić orzecznictwo TSUE wydane po zakończeniu okresu przejściowego, jeśli jest to istotne dla rozpatrzenia danej sprawy. Ponadto w świetle postanowień sekcji 6(7) częścia krajowego prawa brytyjskiego stanie się także orzecznictwo TSUE $\mathrm{w}$ zakresie, w jakim dotyczy prawa, o którym mowa w sekcji 2-4 EUWA 2018. Zatem UK zachowa prawo precedensowe TSUE jako część prawa wewnętrznego, natomiast nie będzie wiążące dla sądów brytyjskich orzecznictwo TSUE wydane po zakończeniu okresu przejściowego. Przepisy pozwalaja także sądom brytyjskim (sekcja 6(5) EUWA 2018) na odstapienie od orzecznictwa TSUE po zastosowaniu tego samego testu, który zastosowałyby przy podejmowaniu decyzji o odejściu od własnego orzecznictwa. Gwarancja zachowania status quo w odniesieniu do określonego w sekcjach 2-4 prawa pochodzenia unijnego jest sekcja 7 EUWA 2018, określająca także - co jest oryginalne dla prawnika kontynentalnego - rangę aktu prawnego, którym można dokonać zmian we wskazanym prawie.

Kolejną ważną zmianą wprowadzoną przez EUWA 2020 jest zwiększenie kontroli parlamentu nad procesem wdrażania postanowień EUWA 2018 przez przyjęcie wymogu uchwalania w tym celu ustaw, a tym samym ograniczenie wynikających z sekcji 8 EUWA 2018 uprawnień rządu do wydawania aktów wykonawczych na podstawie tzw. Henry VIII powers $^{149}$. I tak wejście w życie sekcji 3 „Incorporation of direct EU legislation” oraz sekcji 7 „Status of retained EU law” EUWA 2018 przed jego zmianą było uzależnione od wydania przepisów wykonawczych przez rząd brytyjski (sekcja 25 (4)).

Przyjęty model „zatrzymania” prawa unijnego po upływie okresu przejściowego $\mathrm{w}$ zakresie p.p.m. bez gwarancji wzajemności to $\mathrm{w}$ ocenie ekspertów najgorsze z możliwych rozwiązań. Rząd brytyjski, przenosząc regulacje unijne do prawa brytyjskiego bez zagwarantowania wzajemno-

${ }^{149}$ Rodzaj aktów delegowanych, które umożliwiają ministrom zmianę lub uchylenie ustawodawstwa pierwotnego bez konieczności tworzenia nowego aktu parlamentu, zatem bez kontroli parlamentu. Rząd brytyjski opowiadał się za jego szerokim wykorzystaniem $\mathrm{w}$ procesie prac nad skutkami prawnymi brexitu. Oznacza to w praktyce zwiększenie uprawień rządu kosztem parlamentu (może jedynie przyjąć lub odrzucić akt delegowany przyjęty przez rząd, bez możliwości wprowadzania w nim zmian). Szerokie wykorzystanie Henry VIII powers w pracach nad skutkami prawnymi brexitu było z tego powodu mocno krytykowane. 
ści ${ }^{150}$, musi mieć na względzie, że bez porozumienia z państwami członkowskimi UE nie byłoby wiadomo, jak inne państwa członkowskie UE potraktowałyby orzeczenia brytyjskie. Teoretycznie, w braku umowy wielostronnej lub dwustronnej między UK a danym państwem unijnym, należało stosować przepisy krajowe obowiązujące w poszczególnych państwach unijnych, które zazwyczaj są mniej korzystne niż dotychczasowe regulacje unijne. Eksperci brytyjscy z tego powodu obawiają się jednak opóźnień i dodatkowych kosztów dla brytyjskiego sądownictwa oraz stron postępowań z elementem obcym. Faktem jest, że osoby fizyczne stracą możliwość łatwego egzekwowania orzeczeń brytyjskich w innych państwach członkowskich UE, co ma szczególnie niekorzystny wpływ na rodziny międzynarodowe ${ }^{151}$. Nie do końca można podzielić ten argument w przypadku sądów polskich, biorąc pod uwagę, że w Polsce doszło do „udomowienia” części unijnych regulacji dotyczących jurysdykcji, uznawania i wykonywania zawartych w rozporządzeniu Bruksela I na podstawie nowelizacji przepisów k.p.c. z 2008 r. ${ }^{152}$ Jednak k.p.c. nie znosi exequatur $\mathrm{w}$ przypadku niektórych orzeczeń dotyczących odpowiedzialności rodzicielskiej, jak ma to miejsce w Brukseli II bis.

\subsection{Postanowienia umowy o wystąpieniu w zakresie transgranicznych spraw rodzinnych}

Podstawą umowy o wystapieniu UK z UE jest art. 50 ust. 2 TUE $^{153}$. Umowa między państwem występującym a UE ma określić warunki wystąienia, z uwzględnieniem ram przyszłych stosunków państwa występującego z Unii. Do przyjęcia umowy o wystąpieniu (Agreement on the withdrawal of the United Kingdom of Great Britain and Northern Ireland from the European Union and the European Atomic Energy Community [dalej: umowa o wystapieniu]) doszło ostatecznie 24 stycznia 2020 r. ${ }^{154}$, po długim kryzysie politycznym zakończonym przedtermi-

${ }^{150}$ Por. N. Lowe: „It will not be good enough to adopt the strategy of enacting these [EU family law] instruments domestically since their efficacy depends on reciprocity and orders that are not enforceable are not worth the paper they are written on".

${ }^{151}$ Brexit and Family Law..., s. 20.

${ }_{152}$ Ustawa z dnia 5 grudnia 2008 r. o zmianie ustawy - Kodeks postępowania cywilnego oraz niektórych innych ustaw. Dz.U. 2008, nr 234, poz. 1571, weszła w życie dnia 1 lipca $2009 \mathrm{r}$.

${ }_{153}$ Traktat o Unii Europejskiej z dnia 7 lutego 1992 r. Dz.U. 2004, nr 90, poz. 864 [30].

${ }^{154}$ Umowa o wystapieniu Zjednoczonego Królestwa Wielkiej Brytanii i Irlandii Północnej z Unii Europejskiej i Europejskiej Wspólnoty Energii Atomowej. Dz.Urz. UE L nr 29 , s. 7 . 
nowymi wyborami do Izby Gmin, w których większość uzyskała partia konserwatywna.

$\mathrm{W}$ świetle art. 4 ust. $1 \mathrm{zd} .2$ umowa o wystapieniu korzysta z zasady bezpośredniej skuteczności, tym samym osoby prawne lub fizyczne moga powoływać się bezpośrednio na zawarte lub przywołane w niej postanowienia, które spełniaja warunki bezpośredniej skuteczności na mocy prawa Unii. Przy wdrażaniu i stosowaniu postanowień umowy o wystąpieniu odnoszacych się do prawa Unii lub do jego pojęć, lub przepisów stosuje się wykładnię zgodna z odpowiednim orzecznictwem TSUE wydanym przed zakończeniem okresu przejściowego. Odstapiono także od definitywnego zerwania ze stosowaniem orzecznictwa TSUE po zakończeniu okresu przejściowego, ponieważ w zakresie wykładni umowy organy sądowe i administracyjne UK mają obowiązek należycie uwzględnić odpowiednie orzecznictwo TSUE wydane po zakończeniu okresu przejściowego (art. 4 ust. 4).

Głównym założeniem umowy o wystapieniu w zakresie prawa unijnego jest przyjęcie jego obowiąywania w UK w okresie przejściowym na dotychczasowych zasadach. W świetle art. 127 ust. $1 \mathrm{w}$ zw. z ust. $3 \mathrm{w}$ okresie przejściowym prawo Unii wywołuje takie same skutki prawne w UK i w odniesieniu do UK, jakie wywołuje w UE i w jej państwach członkowskich, oraz jest stosowane zgodnie z tymi samymi metodami i ogólnymi zasadami, jak majace zastosowanie w UE. Z perspektywy pozostałych państw członkowskich UE gwarantuje to ust. 6 art. 127, wskazujacy, że w okresie przejściowym wszelkie odniesienia do państw członkowskich w prawie Unii, w tym wdrażanym i stosowanym przez państwa członkowskie, obejmuja także UK. Konsekwentnie, wszelkie zmiany prawa unijnego dokonane w okresie przejściowym sa prawnie wiążące także w Wielkiej Brytanii po dacie brexitu, a przed upływem okresu przejściowego.

Dla prawa prywatnego międzynarodowego oznacza to pełne respektowanie zasady wzajemności. Zgodnie z art. 126 umowy o wystąpieniu, okres przejściowy rozpoczą się z dniem jej wejścia w życie (tj. 1 lutego 2020 r.) i skończy się 31 grudnia 2020 r., przy czym art. 132 ust. 1 pozwala na jego przedłużenie o maksymalnie rok lub 2 lata ${ }^{155}$. To rodzi wątpliwości interpretacyjne, czy chodzi dokładnie o rok względnie 2 lata, czy też może to być okres krótszy niż rok lub 2 lata. Z jednej strony intencja prawodawcy powinno być precyzyjne określenie wyjątkowej możliwości przedłużenia okresu przejściowego, co mogłoby przemawiać za przyjęciem interpretacji w kierunku „sztywnego” określenia okresu roku lub 2 lat, z drugiej strony zaś - wnioskując a maiore ad minus - przyjać można okres krótszy niż rok, ale nie dłuższy niż 2 lata.

${ }_{155}$ Ang. „extending the transition period for up to 1 or 2 years”. 
Na podstawie tytułu VI Trwajaca wspótpraca sqdowa w sprawach cywilnych $i$ handlowych części trzeciej Postanowienia dotyczqce wystapienia $\mathrm{w}$ zakresie prawa właściwego przepisy unijne sa stosowane w UK do umów zawartych przed zakończeniem okresu przejściowego oraz do zdarzeń powodujących szkodę, które będą miały miejsce przed zakończeniem okresu przejściowego (art. 66) ${ }^{156}$. Z kolei przepisy dotyczące jurysdykcji są stosowane w UK oraz w państwach członkowskich w sytuacjach obejmujących UK w odniesieniu do postępowań sądowych wszczętych przed zakończeniem okresu przejściowego lub spraw pozostających $\mathrm{w}$ związku z takim postępowaniem sądowym (art. 67 ust. 1) ${ }^{157}$. W przypadku uznawania i wykonywania wyroków, orzeczeń, dokumentów urzędowych, ugód sądowych oraz współpracy w tym zakresie między organami centralnymi przepisy unijne sa stosowane w UK do uznawania i wykonywania wyroków wydanych w postępowaniach sądowych wszczętych przed zakończeniem okresu przejśsiowego oraz $\mathrm{w}$ odniesieniu do dokumentów urzędowych, oficjalnie sporządzonych lub zarejestrowanych, do ugód sądowych zatwierdzonych lub zawartych przed zakończeniem okresu przejściowego oraz do pozwów, wniosków, które wpłynęły do organów centralnych lub innych właściwych organów przed zakończeniem okresu przejściowego np. w sprawie o alimenty lub odpowiedzialności rodzicielskiej (art. 67 ust. $2-3)^{158}$. Analogiczna zasada dotyczy postępowań $\mathrm{w}$ toku $\mathrm{w}$ ramach współpracy wymiarów sprawiedliwości, a dokładnie w zakresie doręczania dokumentów sądowych i pozasądowych oraz przeprowadzania dowodów za granica, które wpłynęły przed zakończeniem okresu przejściowego do właściwych podmiotów (art. 68 umowy o wystapieniu).

Przepisy przejściowe przewidują także utrzymanie $\mathrm{w}$ całości mocy wiążącej w UK wyroków i postanowień TSUE wydanych przed zakończeniem okresu przejściowego oraz $\mathrm{w}$ ramach wszelkich postępowań wszczętych ${ }^{159}$ przed TSUE przez UK lub przeciwko UK przed zakończeniem okresu przejściowego w odniesieniu do wszystkich etapów po-

${ }_{156}$ Chodzi o rozporządzenie nr 593/2008 oraz rozporządzenie nr 864/2007.

${ }_{157}$ Chodzi o rozporządzenia numer: 1215/2012, 2017/1001, 6/2002, 2100/94, 2016/679, 2201/2003, 4/2009, oraz o dyrektywę 96/71/WE [dyrektywa 96/71/WE Parlamentu Europejskiego i Rady z dnia 16 grudnia 1996 r. dotycząca delegowania pracowników w ramach świadczenia usług. Dz.Urz. L nr 18, 21.01.1997, s. 1].

${ }_{158}$ Chodzi o rozporządzenia numer: 2201/2003, 4/2009, 2015/848, 1896/2006, 861/2007, 606/2013.

159 Por. art. 86 ust. 3 umowy o wystąpieniu: „postępowania zostały wszczęte przed Trybunałem Sprawiedliwości Unii Europejskiej, a wnioski o wydanie orzeczenia w trybie prejudycjalnym zostały złożone w dniu wpisania do rejestru dokumentu wszczynajacego postępowanie przez Sekretariat Trybunału Sprawiedliwości lub Sądu, odpowiednio do przypadku". 
stępowania, w tym postępowań odwoławczych przed Trybunałem i postępowań przed Sądem, jeżeli sprawa została skierowana do ponownego rozpoznania przez Sąd (art. 89 w zw. z art. 86 ust. 1). TSUE jest także właściwy do wydawania orzeczeń w trybie prejudycjalnym na wnioski sądów Zjednoczonego Królestwa złożone przed zakończeniem okresu przejściowego (art. 86 ust. 2). Z tej perspektywy za miarodajny uznaje się dzień wpisania do rejestru dokumentu wszczynającego postępowanie przez Sekretariat Trybunału lub Sądu (ust. 3 art. 86). Ponadto na podstawie art. 87 umowy o wystąpieniu możliwe jest wszczęcie nowej sprawy przed TSUE w ciągu 4 lat po zakończeniu okresu przejściowego, jeżeli Komisja Europejska stwierdziłaby brak wypełnienia przez UK obowiązku wynikającego z Traktatów lub części IV umowy dotyczącej okresu przejściowego.

Zatem data 31 grudnia 2020 r. nie oznacza automatycznego kresu obowiązywania w UK prawa unijnego. Taki skutek będzie z kolei wiązany z faktem zawarcia umowy, nastąpienia zdarzenia powodującego szkodę, wszczęcia postępowania, złożenia wniosku o uznanie lub wykonanie zagranicznego orzeczenia, doręczenie dokumentów, przeprowadzenie dowodów, wydanie zaświadczenia itd. na podstawie przepisów unijnych po tej dacie.

Dzięki przyjęciu umowy o wystapieniu zażegnano niebezpieczeństwo twardego brexitu, bez umowy, kiedy to prawo unijne przestałoby wiązać UK automatycznie z dniem wyjścia z UE, co rodziłoby dużą niepewność prawna w związku z brakiem jakichkolwiek przepisów przejściowych.

\section{Wnioski końcowe. Okres przejściowy i co dalej?}

Z perspektywy transgranicznych spraw rodzinnych przyjęcie umowy wprowadzającej okres przejściowy oznacza zyskanie czasu na negocjacje $\mathrm{w}$ sprawie szczegółów przyszłych relacji między UK a państwami członkowskimi UE, w tym Polska. Wciąż otwarte pozostaje pytanie, jakie będą te relacje, czy przyjma formę umów dwustronnych między UK a państwami członkowskim, czy umów wielostronnych, a może umowy dwustronnej między UK a UE ze skutkami dla wszystkich państw członkowskich. Zgodnie z procedurą określoną w art. 218 TFUE, wszelkie umowy między państwami członkowskimi a krajami trzecimi powinny być negocjowane i zawierane przez UE, nawet jeżeli taką umowa zainteresowane jest tylko jedno państwo członkowskie. Ponadto UE na 
podstawie rozporządzenia $\mathrm{nr} 664 / 2009$ z dnia 7 lipca 2009 r. ${ }^{160}$ ma wyłączną kompetencję zewnętrzną w zakresie negocjowania i zawierania umów dwustronnych pomiędzy państwami członkowskimi a państwami trzecimi dotyczacych jurysdykcji, uznawania i wykonywania orzeczeń i decyzji w sprawach małżeńskich, dotyczących odpowiedzialności rodzicielskiej oraz związanych z zobowiazaniami alimentacyjnymi (w tym prawa właściwego dla alimentów). Komisja Europejska może upoważnić państwo członkowskie do zawarcia umowy z państwem trzecim, wyłącznie jeśli stwierdzi brak interesu UE do zawarcia takiej umowy. Komisja nie udzieli państwu członkowskiemu upoważnienia do zawarcia takiej umowy, jeśli w niedalekiej przyszłości organy UE planuja jej zawarcie (art. 4 rozporządzenia $\mathrm{nr}$ 664/2009). Będąca uzasadnieniem dla wyłącznej kompetencji UE w zakresie zawierania umów dwustronnych obawa naruszenia unijnego dorobku prawnego opartego na koncepcji integralności i pewności prawnej obywateli europejskich dotyczy w równym stopniu umów wielostronnych. Także z opinii 1/03 z dnia 7 lutego 2006 r. $^{161}$ wynika, że UE posiada wyłączna kompetencję do zawarcia w imieniu państw członkowskich z państwami trzecimi umów wielostronnych. Opinia dotyczyła Konwencji lugańskiej z 2007 r. o jurysdykcji oraz o uznawaniu i wykonywaniu orzeczeń sądowych w sprawach cywilnych i handlowych, lecz per analogiam jest często powoływana w zakresie współpracy sądowej w sprawach cywilnych i handlowych względnie instrumentów rozwoju przestrzeni wolności, sprawiedliwości i bezpieczeństwa.

Rozporządzanie nr 664/2009 nie wiąże Danii, zatem de facto żadne inne państwo członkowskie, oprócz Danii (w tym Polska), nie ma kompetencji do zawierania po zakończeniu okresu przejściowego umów z UK jako państwem trzecim.

Dzisiaj jest wysoce prawdopodobne, że po zakończeniu okresu przejściowego UK przystapi do Konwencji haskiej z 2007 r. o międzynarodowym dochodzeniu alimentów na rzecz dzieci i innych członków rodziny oraz do Konwencji lugańskiej z 2007 r. o jurysdykcji i uznawaniu oraz

${ }^{160}$ Rozporządzenie Rady (WE) nr 664/2009 z dnia 7 lipca 2009 r. ustanawiające procedurę negocjowania i zawierania umów pomiędzy państwami członkowskimi a państwami trzecimi dotyczących jurysdykcji, uznawania i wykonywania orzeczeń i decyzji w sprawach małżeńskich, w sprawach dotyczących odpowiedzialności rodzicielskiej oraz w sprawach związanych z zobowiązaniami alimentacyjnymi, a także prawa właściwego w sprawach dotyczących zobowiązań alimentacyjnych. Dz.Urz. UE L nr 200, t. 52, 31.07.2009, s. 46.

${ }^{161}$ Zb. Orz ETS (2006) s. I-1145; szerzej por. M. Niedźwiedź, P. Mostowik: Wspólnota Europejska jako strona umów międzynarodowych $w$ dziedzinie prawa prywatnego międzynarodowego. Uwagi na tle opinii Trybunatu Sprawiedliwości WE w sprawie 1/03. „Problemy Współczesnego Prawa Międzynarodowego, Europejskiego i Porównawczego" 2009, vol. 7, s. 71. 
wykonywaniu orzeczeń sądowych w sprawach cywilnych i handlowych. Natomiast dotychczas nie ma oficjalnego stanowiska żadnej ze stron w zakresie jurysdykcji w sprawach rozwodu (separacji), odpowiedzialności rodzicielskiej czy uprowadzenia dziecka za granicę. Wciąż otwarta jest kwestia, czy będzie możliwe automatyczne „odżycie” w Wielkiej Brytanii Konwencji haskiej z 1980 r. o cywilnych aspektach uprowadzenia dziecka za granicę oraz Konwencji haskiej z 1996 r. o jurysdykcji, prawie właściwym, uznawaniu, wykonywaniu i współpracy w zakresie odpowiedzialności rodzicielskiej oraz środków ochrony dzieci.

W braku wypracowania konkretnych rozwiązań do końca okresu przejściowego sądy państw członkowskich UE oraz sądy brytyjskie moga stanaćc przed dylematem, czy stosować postanowienia umów międzynarodowych, a w ich braku - regulacje krajowe.

Trzeba też mieć na uwadze, że w założeniu pomysł „zatrzymania” prawa unijnego miał być rozwiązaniem tymczasowym, które pozwoliłoby parlamentom brytyjskim na decydowanie o tym, jaki dorobek prawny każdy z nich chce przyjać i dostosować za pomoca krajowego prawa wtórnego ${ }^{162}$. Jak wynika z wcześniejszych rozważań, nie zawsze będzie możliwy automatyczny powrót do stosowania konwencji haskich. W braku innego rozwiązania sądy brytyjskie mogą wrócić do stosowania common law.

\section{Bibliografia}

Beaumont P.: A Critical Analysis of the Judicial Activism of the Court of Justice of the European Union in Opinion 1/13. In: The External Action of the EU in the Field of Private International Law after Opinion 1/13. Ed. P. Franzina. Intersentia 2016.

Beaumont P.: Private international law concerning children in the UK after Brexit: comparing Hague Treaty Law with EU Regulations, www.abdn. ac.uk/law/documents/CPIL\%20Working\%20Paper\%20No\%202017_2.pdf [Dostęp: 2.07.2019 r.].

Brand R.A.: Implementing the 2005 Hague Convention: The EU Magnet and the US Centrifuge. „Legal Studies Research Paper Series: Working Paper” no. 2013-20 (2013).

Brexit and Family Law, October 2017, Family Law Bar Association (FLBA), International Academy of Family Lawyers (IAFL), https://www.resolution. org.uk [Dostęp: 17.02.2020 r.].

Briggs A.: The conflict of law. 3 th. Oxford University Press 2013.

Cheshire G.C.: Private International Law. London 1965.

162 J. Fitchen: The Private International Law..., s. 418. 
Curtin D.: The ties that bind. Securing information-sharing after Brexit. In: Brexit and Beyond: Rethinking the Futures of Europe. Eds. B. Martill, U. Staiger. UCL Press 2018.

Dicey, Morris and Collins on the Conflict of Laws. Ed. L. Collins. 14 th. London, Sweet\&Maxwell, 2006.

Dickinson A.: United Kingdom. In: Encyclopedia of private international law, National reports. Vol. 3. Eds. J. Basedow, G. Rühl, F. Ferrari, P. de M. Asensio. Cheltenham, Edward Elgar Publishing, 2017.

Doyle M.: The impact of Brexit on children and young people in Scotland, Case study on cross-border family law. Together (Scottish Alliance for Children's Rights).

Fawcett J.J., Carruthers J.M., North P.M., Cheshire, North and Fawcett: Private international law. 14 th. Oxford [etc.], Oxford University Press, 2008.

Fitchen J.: The Private International Law Consequences of Brexit. „Nederlands Internationaal Privaatrecht" 2017, no. 3.

Główny Urząd Statystyczny: Informacja o rozmiarach $i$ kierunkach czasowej emigracji $z$ Polski w latach 2004-2016. Warszawa 2017, https://stat. gov.pl/obszary-tematyczne/ludnosc/migracje-zagraniczne-ludnosci/infor macja-o-rozmiarach-i-kierunkach-czasowej-emigracji-z-polski-w-latach2004-2017,2,11.html [Dostęp: 2.04.2019 r.].

Guidance Toponymic guidelines for map and other editors, United Kingdom of Great Britain and Northern Ireland. Updated, 17 July 2019, https://www. gov.uk/government/publications/toponymic-guidelines/toponymic-guidelines-for-map-and-other-editors-united-kingdom-of-great-britain-and-northernireland\#abbreviations-encountered-in-official-mapping [Dostęp: 9.10.2019 r.].

Gumuła-Kędracka J.: Brexit a reforma rozporzadzenia Bruksela II bis. W: Unia Europejska w przededniu Brexitu. Red. J. Barcik, M. Półtorak. Warszawa 2018.

Hawkins O., Moses A.: Polish population of the United Kingdom. „Briefing Paper”, CBP7660, 15 July 2016.

Komisja Standaryzacji Nazw Geograficznych poza Granicami Rzeczypospolitej Polskiej przy Głównym Geodecie Kraju: Nazwy państw. Główny Urzqd Geodezji i Kartografii. Warszawa 2006.

Kubas S.: Brexit a swoboda przeptywu osób z polskiej perspektywy. W: Unia Europejska w przededniu Brexitu. Red. J. Barcik, M. Półtor a k. Warszawa 2018.

Lein E.: Litigation post Brexit, s. 3, https://www.biicl.org/documents/1532 faq_-_litigation_post_brexit.pdf?showdocument=1 [Dostęp: 15.07 .2019 r.].

Lowe N.: Some reflections on the options for dealing with international family law following Brexit. „Family Law” 2017, vol. 399.

McClean D.: Morris, The Conflict of Laws. Eds. D. McClean, V. Ruiz Abou-Nig m. 8 th. London 2012.

Mostowik P., Sondel-Maciejewska K.: Materialnoprawne rezultaty unijnej wspótpracy sqdowej $w$ sprawach rodzinnych. W: Wspótczesne wyzwania prawa prywatnego międzynarodowego. Red. J. Poczobut. Warszawa 2013. 
Niedźwiedź M., Mostowik P.: Wspólnota Europejska jako strona umów międzynarodowych $w$ dziedzinie prawa prywatnego międzynarodowego. Uwagi na tle opinii Trybunatu Sprawiedliwości WE w sprawie 1/03. „Problemy Współczesnego Prawa Międzynarodowego, Europejskiego i Porównawczego” 2009, vol. 7.

Pilich M.: Brexit and EU private international law: May the UK stay in?. „Maastricht Journal of European and Comparative Law” August 2017, 20 (10).

Pisani-Ferry J. et al.: Europe after Brexit: A proposal for a continental partnership. Bruegel 2016.

Shaw J.: Citizenship and free movement in a changing EU: Navigating an archipelago of contradictions. In: Brexit and Beyond: Rethinking the Futures of Europe. Eds. B. Martill, U. Staiger. UCL Press 2018.

UK White Paper, The United Kingdom's exit from and new partnership with the European Union, 2.3, 2.8, A.20, https://assets.publishing.service.gov.uk/ government/uploads/system/uploads/attachment_data/file/589191/The_Uni ted_Kingdoms_exit_from_and_partnership_with_the_EU_Web.pdf[Dostęp: 24.07.2019 r.].

Wagner R.: Do We Need a Rome 0 Regulation? „Netherlands International Law Review" 2014/61.

Williams D., Bailey Harris R.: Select Committee on the European Union Justice Sub-Committee Corrected oral evidence: Brexit: civil justice cooperation and the CJEU, s. 7-8, http://data.parliament.uk/writtenevidence/ committeeevidence.svc/evidencedocument/eu-justice-subcommittee/brexitcivil-justice-cooperation/oral/44261.pdf [Dostęp: 5.07.2019 r.]. 